Supplementary Information for

\title{
Atmospheric Nitrate Formation through Oxidation by Carbonate Radical
}

Xiaozhong Fang, ${ }^{1 *}$ Yangyang Liu, ${ }^{1 *}$ Kejian Li,${ }^{1}$ Tao Wang, ${ }^{1}$ Yue Deng, ${ }^{1}$ Yiqing Feng, ${ }^{1}$ Yang Yang, ${ }^{1}$ Hanyun Cheng, ${ }^{1}$ Jianmin Chen, ${ }^{1}$ Liwu Zhang ${ }^{1,2 *}$

${ }^{1}$ Shanghai Key Laboratory of Atmospheric Particle Pollution and Prevention, Department of Environmental Science and Engineering, Fudan University, Shanghai, 200433, the People's Republic of China

${ }^{2}$ Shanghai Institute of Pollution Control and Ecological Security, Shanghai, 200092, the People's Republic of China. 


\section{Catalogue}

Text S1. samplings of atmospheric particulate matter............................4

Text S2. quantification of (bi)carbonate ions...............................4

Scheme S1. schematic diagram of transient spectroscopy instrument......................6

Scheme S2. the thin-film sample preparation process........................6

Scheme S3. schematic diagram of the structure of adsorbed and solvated nitrate.....7

Scheme S4. surface species transform of $\mathrm{NO}_{2}$ adsorption...................................

Table S1. Parameters used for uptake coefficient calculation...................8

Table S2. The $\mathrm{pH}$ of the leaching solution of $\mathrm{CaCO}_{3} / \mathrm{CaO}+\mathrm{TiO}_{2} \ldots \ldots \ldots \ldots \ldots \ldots . . . . .9$

Table S3. assignment of vibrational frequencies............................... 9

Table S4. assignment of surface varied species.....................................................13

Figure S1. the $\mathrm{PM}_{2.5}$ and corresponding $\mathrm{NO}_{2}, \mathrm{SO}_{2}$ daily average concentration....14

Figure S2. sketch drawing of the reaction system.............................. 15

Figure S3. spectral distribution of the Xenon lamp light........................16

Figure S4. linear relationship between the ion concentration and mass...................16

Figure S5. calibration plot for Conversion-factor.......................... 17

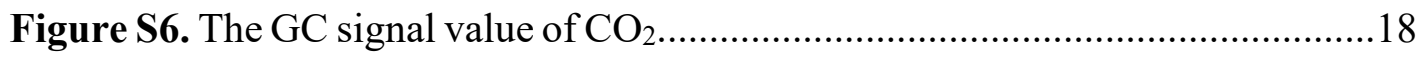

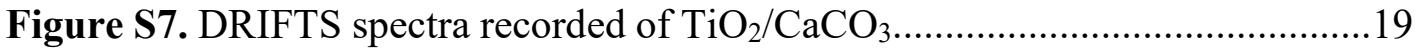

Figure S8. DRIFTS spectra recorded of Proxy1 exposed to $\mathrm{NO}_{2} \ldots \ldots \ldots \ldots \ldots \ldots \ldots \ldots . . . . . .20$

Figure S9. calibration plot of surface nitrate versus time......................21

Figure S10. the time-dependent uptake coefficient...........................................21

Figure S11. average $\mathrm{PM}_{2.5}$ concentration on the sampling date..................22 
Figure S12. correlation involving the sulfate and organic matter. 22

Figure S13. correlation between the $\mathrm{pH}$ and the nitrate/(bi)carbonate. .23

Figure S14. six basis vectors and the singular values for TA spectra matrix .24

Figure S15. the biexponential fitted TA spectra...........................25

Figure S16. $\mathrm{CO}_{3}^{\bullet-}$ TA signal in literature...................................25

Figure S17. $\mathrm{CO}_{3}^{\bullet-}$ TA signal in liquid phase...................................26

Figure S18. light intensity and humidity dependence.........................................26

Figure S19. the integral KM of nitrate production..........................27

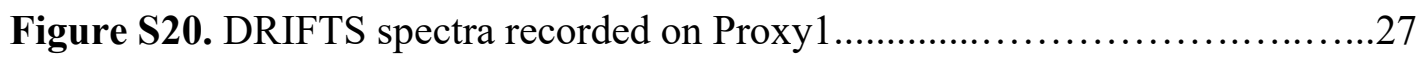

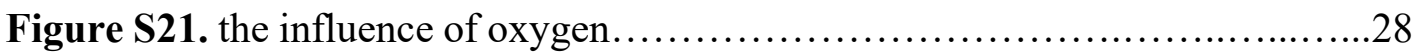


Text S1. Samplings of atmospheric particulate matter. Sampling was carried out on the roof of the Department of Environmental Science and Engineering of Fudan University (Jiangwan Campus) by using an 8 Stage Non-viable Cascade Impactor (Tish Environmental, Inc., USA), the size gradient of which for different stages are $0-0.4$, $0.4-0.7,0.7-1.1,1.1-2.1,2.1-3.3,3.3-4.7,4.7-5.8,5.8-9.0$ and $>9.0 \mu \mathrm{m}$. These sizes represent the effective cut-points diameter $(\mu \mathrm{m})$ at each stage. The sampling time in winter is from 17 January 2019 to 2 January 2020 and in autumn is from 22 September 2018 to 29 September 2018, 15 December 2019 and 17 December 2019. Before sampling, the sampling pump was calibrated to $28.3 \mathrm{~L} / \mathrm{min}$ since the size fraction for each stage is determined by the orifice velocities. To give an insight into the influence of light we separated our daily sampling into two periods, which was 11 hours for each daytime (7:30 - 18:30) and nighttime (19:30 - 6:30). Quartz microfiber filters (81 $\mathrm{mm}$ in diameter, GE Healthcare UK Limited) used for sampling were pretreated with ultrapure water (Ultrasonic for 40 minutes and then rinse twice with ultrapure water) and then dry with an infrared oven, followed by packing them in aluminum foils before field sampling.

Text S2. Quantification of (bi)carbonate ions. We estimated the concentration of (bi)carbonate based on the differences between the measured cations and anions because we cannot directly determine it as a result of the chromatographic eluent containing (bi)carbonate. The Particle with a diameter less than $2 \mu \mathrm{m}$ cannot obtain (bi)carbonate concentration by our method because these particles consist of the secondary aerosol with the particle size of Aitken mode and accumulation mode $(<2$ 
$\mu \mathrm{m})$, resulting in the detected anion concentration was higher than cation. But our method is still rational considering the particle size distribution of mineral dust in the atmosphere. Two assumptions were initially raised to simplify this estimation: a. dominating cation ions in consideration are $\mathrm{H}^{+}, \mathrm{Li}^{+}, \mathrm{Na}^{+}, \mathrm{NH}^{4+}, \mathrm{K}^{+}, \mathrm{Mg}^{2+}$ and $\mathrm{Ca}^{2+}$ whereas those transition and heavy metal ions were out of consideration given their limited contents in the particle matter; b. only four major organic acid ions in the atmosphere $\left(\mathrm{CH}_{3} \mathrm{COO}^{-}, \mathrm{COOH}^{-}, \mathrm{CH}_{3} \mathrm{CHOHCOO}^{-}\right.$and $\left.\mathrm{C}_{2} \mathrm{O}_{4}{ }^{2-}\right)$ are taken into accounts for ionization balance and the rest of the charge gap were assumed to originate from (bi)carbonate ions. Then we established the balance equations (eq. S1) for each sample based on charge conservation and ionization equilibrium of carbonic acid (eq. S1 - eq.

$$
\begin{aligned}
& \left.\mathrm{S} 3, \mathrm{~K}_{1}=4.3 \times 10^{-7} \text { and } \mathrm{K}_{2}=4.8 \times 10^{-11} \text { at } 298 \mathrm{~K}\right) \\
& {\left[\mathrm{H}^{+}\right]+\left[\mathrm{Li}^{+}\right]+\left[\mathrm{Na}^{+}\right]+\left[\mathrm{NH}_{4}^{+}\right]+\left[\mathrm{K}^{+}\right]+2\left[\mathrm{Mg}^{2+}\right]+2\left[\mathrm{Ca}^{2+}\right]=\left[\mathrm{OH}^{-}\right]+\left[\mathrm{F}^{-}\right]+} \\
& {\left[\mathrm{CH}_{3} \mathrm{COO}^{-}\right]+\left[\mathrm{CH}_{3} \mathrm{CHOHCOO}^{-}\right]+\left[\mathrm{COOH}^{-}\right]+\left[\mathrm{NO}_{2}^{-}\right]+\left[\mathrm{Cl}^{-}\right]+\left[\mathrm{NO}_{3}^{-}\right]+} \\
& {\left[\mathrm{Br}^{-}\right]+3\left[\mathrm{PO}_{4}^{3-}\right]+2\left[\mathrm{SO}_{4}^{2-}\right]+2\left[\mathrm{C}_{2} \mathrm{O}_{4}^{2-}\right]} \\
& +\left[\mathrm{HCO}_{3}^{-}\right]+2\left[\mathrm{CO}_{3}^{2-}\right] \\
& {\left[\mathrm{HCO}_{3}^{-}\right]=\frac{\mathrm{K}_{1}\left[\mathrm{H}_{2} \mathrm{CO}_{3}\right]}{\left[\mathrm{H}^{+}\right]}} \\
& {\left[\mathrm{CO}_{3}^{2-}\right]=\frac{\mathrm{K}_{1} \mathrm{~K}_{2}\left[\mathrm{H}_{2} \mathrm{CO}_{3}\right]}{\left[\mathrm{H}^{+}\right]^{2}}}
\end{aligned}
$$

Where $[\mathrm{X}]$ refers to the concentration of ion $\mathrm{X}$.

We then solve those equations to obtain the concentration of (bi)carbonate, which were finally corrected by subtracting blank concentration of the membrane. 
Scheme S1. Schematic diagram of NTAS-100 transient spectroscopy instrument.

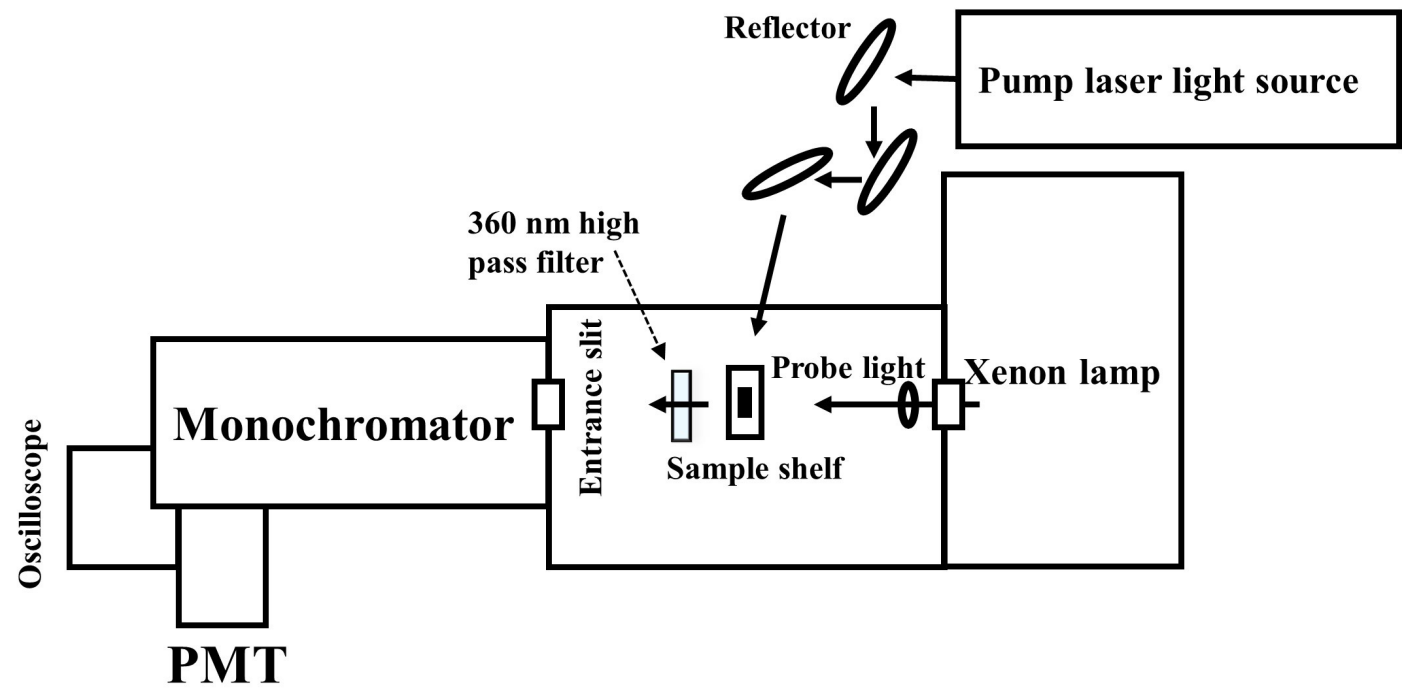

PMT: Photomultiplier tube R928 from Hamamatsu;

Monochromator from Zolix Co., Ltd;

Oscilloscope from Tektronix Co., Ltd;

Laser light source: Nimma series laser from Beamtech Optronics Co., Ltd.

Scheme S2. The thin-film sample preparation process.

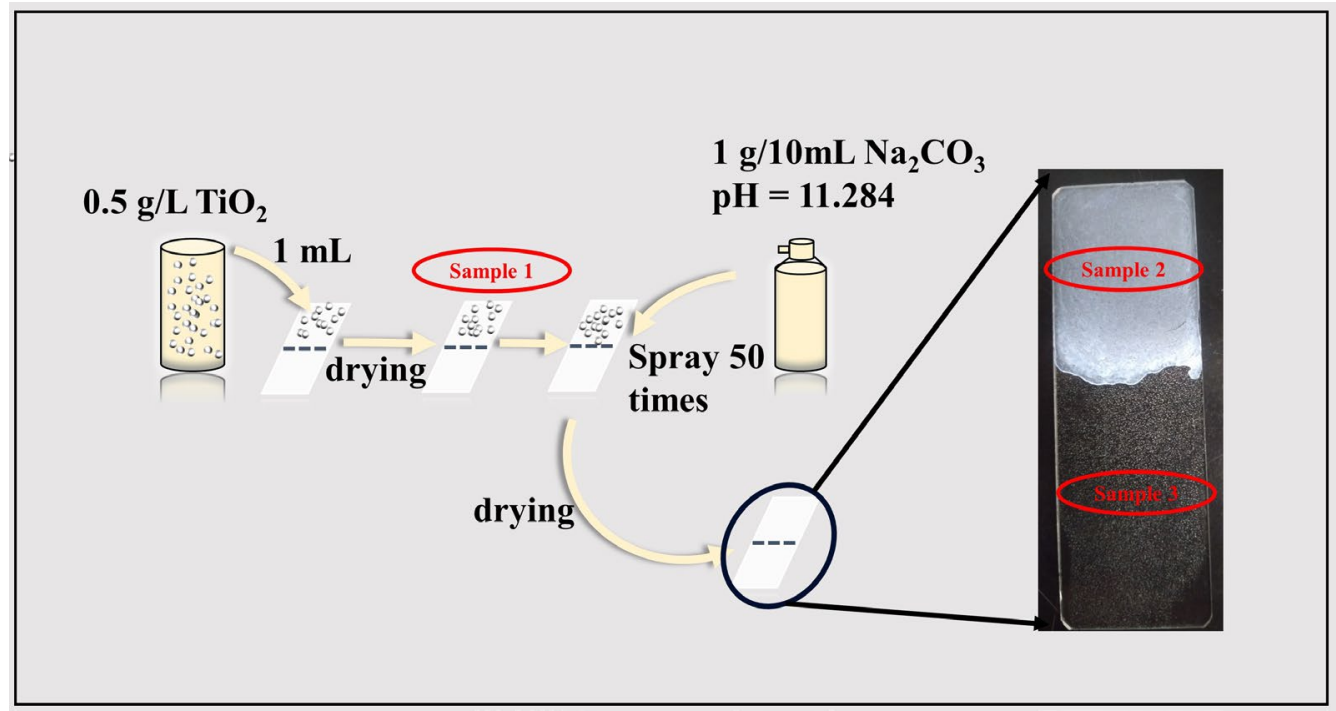

$0.5 \mathrm{~g} / \mathrm{L} \mathrm{TiO}_{2}$ suspension was uniformly dispersed by oscillating for $10 \mathrm{~min}$. Then 1 $\mathrm{ml}$ suspension was dropped on one side of the glass slide. After drying the slide using an infrared oven, it was used to measure the TA spectra of $\mathrm{TiO}_{2}$ film (sample 1). The 
same slide was then sprayed 50 times with $0.1 \mathrm{~g} / \mathrm{mL} \mathrm{Na}_{2} \mathrm{CO}_{3}(\mathrm{pH}=11.28)$. After drying with a hairdryer, it was used to measure the TA spectra of $\mathrm{TiO}_{2}+\mathrm{Na}_{2} \mathrm{CO}_{3}$ film (sample 2) and $\mathrm{Na}_{2} \mathrm{CO}_{3}$ film (sample 3). The intensity of the excitation pulsed-laser (355 nm, laser pulse $9 \mathrm{~ns}$ ) during thin-film experiments is $4.38 \mathrm{~mJ}$. The entrance slit of the monochromator was $1 \mathrm{~mm}$ and the relative light intensity was $30 \mathrm{mV}$. The detection wavelength scanned from $370 \mathrm{~nm}$ to $690 \mathrm{~nm}$ with an interval of $5 \mathrm{~nm}$, and the scan for each wavelength was an average of 50 single shot scans.

Scheme S3. Schematic diagram of the structure of adsorbed and solvated nitrate coordinated on the surface sites of particulate matter (denoted as ' $M$ ').

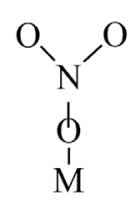

Monodentate nitrate<smiles>[O]N1ONO1</smiles>

Bidentate nitrate

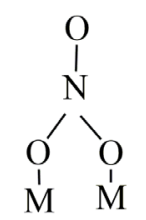

Bridging nitrate

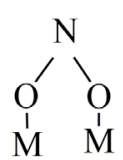

Bidentate nitrito

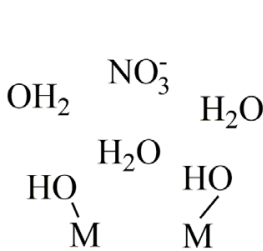

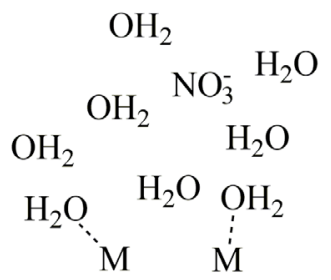

Partially solvated nitrate

Solvated nitrate 
Scheme S4. Surface species transform of $\mathrm{NO}_{2}$ adsorption on mineral dust containing $\mathrm{TiO}_{2}$ and $\mathrm{CaCO}_{3}$. The yellow path represents reactions involving irradiation.

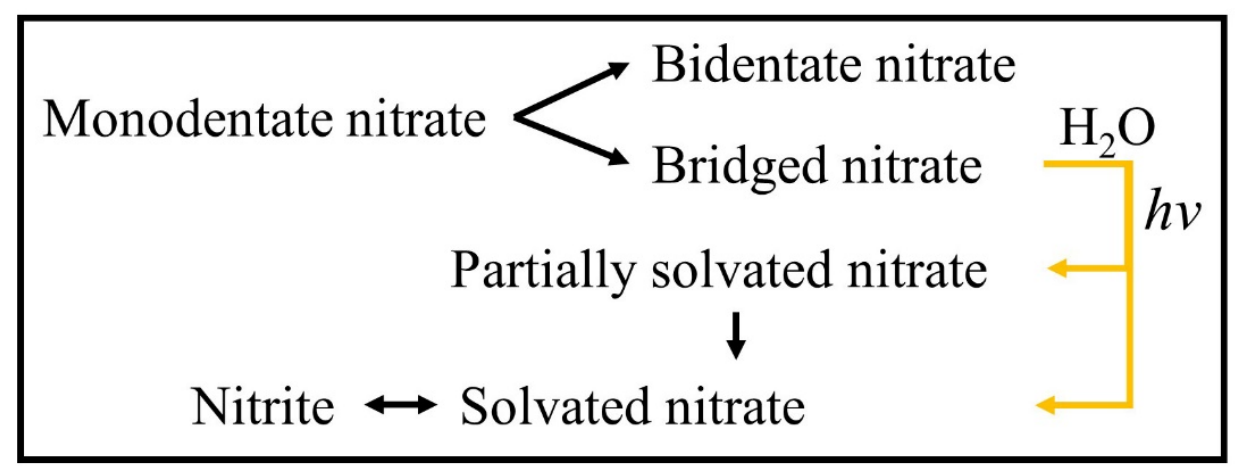

Table S1. Parameters used for uptake coefficient calculation.

\begin{tabular}{|c|c|}
\hline Parameter (unit) & Value \\
\hline $\mathrm{d}\left[\mathrm{NO}_{3}^{-}\right] / \mathrm{dt} \quad\left({ }^{*}\right.$ E17 molecules $\left.\mathrm{g}^{-1} \mathrm{~s}^{-1}\right)$ & Slope $\times f$ \\
\hline Slope $\left(\mathrm{KM} \mathrm{s}^{-1}\right)$ & $d[\mathrm{KM}] / d t$ \\
\hline Conversion factor, $f$ (molecules $\mathrm{KM}^{-1} \mathrm{~g}^{-1}$ ) & 16.91 \\
\hline$A_{\text {BET }}\left(m^{2} g^{-1}\right)$ & 153 \\
\hline$\left[\mathrm{NO}_{2}\right]\left(\right.$ molecules $\left.\mathrm{m}^{-3}\right)$ & $\frac{\mathrm{n} * N_{A}}{24.464} * 10^{-3}$ \\
\hline Avogadro number, $\mathrm{N}_{\mathrm{A}}$ (dimensionless) & $6.022 \times 10^{23}$ \\
\hline $\mathrm{n}\left(\mathrm{NO}_{2}\right.$ concentration, $\left.\mathrm{ppm}\right)$ & 5 \\
\hline $\mathrm{R}\left(\mathrm{J} \mathrm{mol}^{-1} \mathrm{~K}^{-1}\right)$ & 8.314 \\
\hline$M_{\mathrm{NO}_{2}}\left(\mathrm{~kg} \mathrm{~mol}^{-1}\right)$ & $4.6 \times 10^{-2}$ \\
\hline Pi: $\pi$ (dimensionless) & 3.141 \\
\hline
\end{tabular}


Table S2. The $\mathrm{pH}$ of the leaching solution of $\mathrm{CaCO}_{3} / \mathrm{CaO}+\mathrm{TiO}_{2}$ particles before and after exposure to $5 \mathrm{ppm} \mathrm{NO}_{2}$ for the indicated time.

\begin{tabular}{ccc}
\hline & \multicolumn{2}{c}{ Time (min) } \\
\cline { 2 - 3 } Particles & 0 & 30 \\
\hline $0.625 \mathrm{mg} \mathrm{CaCO}+0.625 \mathrm{mg} \mathrm{TiO}_{2}$ & 9.27 & 9.25 \\
$0.625 \mathrm{mg} \mathrm{CaO}+0.625 \mathrm{mg} \mathrm{TiO} 2$ & 11.26 & 11.29 \\
\hline
\end{tabular}

Despite that there is difference between bulk leaching solution and micro aqueous media, $\mathrm{pH}$ measurements at least enable us to ensure that relatively fair environments have been built for these two systems for subsequent reaction processes. Clearly, $\mathrm{CaO}$ retains the surface of $\mathrm{TiO}_{2}$ particles at a higher local $\mathrm{pH}$ environment than $\mathrm{CaCO}_{3}$ does. If buffering effect is major contributor to the overall increase of nitrate yield, a higher $\mathrm{NO}_{2}$ uptake could be expected and seen over $\mathrm{TiO}_{2}-\mathrm{CaO}$ surfaces. However, this expectation is opposite to our observations. In this case, $\mathbf{C O}_{3}^{--}$-involved pathway is more important.

Table S3. Assignment of vibrational frequencies of surface species produced on Proxy1 following the adsorption of $\mathrm{NO}_{2}$ at $296 \mathrm{~K}^{\mathrm{a}}$. 


\begin{tabular}{|c|c|c|c|c|c|c|c|c|}
\hline \multirow{3}{*}{$\begin{array}{l}\text { Surface } \\
\text { species }\end{array}$} & \multirow{3}{*}{$\begin{array}{l}\text { Vibrational } \\
\text { mode } \\
\text { assignment }\end{array}$} & \multirow{3}{*}{$\begin{array}{l}\text { this } \\
\text { work } \\
\left(\mathrm{cm}^{-1}\right)\end{array}$} & \multicolumn{5}{|c|}{ In literature $\left(\mathrm{cm}^{-1}\right)$} & \multirow[t]{3}{*}{ Refs. } \\
\hline & & & \multirow[t]{2}{*}{$\mathrm{SiO}_{2}$} & \multirow[t]{2}{*}{$\mathrm{CaCO}_{3}$} & \multirow[t]{2}{*}{$\mathrm{Al}_{2} \mathrm{O}_{3}$} & \multirow[t]{2}{*}{$\mathrm{TiO}_{2}$} & \multirow[t]{2}{*}{$\sim$} & \\
\hline & & & & & & & & \\
\hline Oxide- & Monodentate & & & & & & & \\
\hline \multicolumn{9}{|c|}{ coordinated } \\
\hline \multicolumn{9}{|l|}{ nitrate } \\
\hline & $v_{3, \text { high }}$ & 1558 & & & $1547-$ & 1509 & $1400-$ & 1 \\
\hline & & 1541 & & & 1529 & 1507 & 1370 & \\
\hline & & 1522 & & & 1555 & & & \\
\hline & & 1506 & & & & & & \\
\hline & \multicolumn{8}{|l|}{ Bidentate } \\
\hline & \multirow[t]{3}{*}{$v_{3, \text { high }}$} & 1576 & & & $1594-$ & 1581 & & \multirow[t]{3}{*}{2,3} \\
\hline & & 1594 & & & 1573 & 1578 & & \\
\hline & & & & & 1552 & 1572 & & \\
\hline & \multicolumn{8}{|l|}{ Bridged } \\
\hline & \multirow[t]{5}{*}{$v_{3, \text { high }}$} & $1678-$ & & & 1661 & $1644-$ & & \multirow[t]{5}{*}{$2-5$} \\
\hline & & 1659 & & & $1630-$ & 1628 & & \\
\hline & & 1636 & & & 1610 & 1636 & & \\
\hline & & 1622 & & & 1599 & 1631 & & \\
\hline & & 1616 & & & & & & \\
\hline
\end{tabular}




\begin{tabular}{|c|c|c|c|c|c|c|c|c|}
\hline \multicolumn{9}{|l|}{$\begin{array}{l}\text { Water- } \\
\text { solvated }\end{array}$} \\
\hline \multicolumn{9}{|l|}{ nitrate } \\
\hline & \multirow[t]{3}{*}{$v_{3, \text { high }}$} & \multicolumn{3}{|l|}{1448} & 1399 & 1406 & 1440 & $2,3,6$ \\
\hline & & \multicolumn{3}{|l|}{1435} & \multicolumn{4}{|l|}{1448} \\
\hline & & \multicolumn{7}{|l|}{1396} \\
\hline & \multirow[t]{3}{*}{$v_{3, \text { low }}$} & 1362 & & 1330 & 1356 & 1331 & \multirow[t]{3}{*}{1330} & \multirow[t]{3}{*}{$3,4,7$} \\
\hline & & 1354 & & & 1350 & 1336 & & \\
\hline & & $/ 1338$ & & & & 1348 & & \\
\hline Partially- & $v_{3, \text { high }}$ & 1489 & & & 1489 & & & 3 \\
\hline solvated & & 1456 & & & 1459 & & & \\
\hline \multirow[t]{2}{*}{ nitrate } & & 1429 & & & 1421 & & & \\
\hline & & 1418 & & & 1416 & & & \\
\hline \multirow[t]{3}{*}{ Nitrite ion } & \multirow[t]{3}{*}{$v^{s}\left(\mathrm{NO}_{2}^{-}\right)$} & 1387 & & & & & $1390-$ & \multirow[t]{3}{*}{8} \\
\hline & & 1373 & & & & & 1335 & \\
\hline & & $/ 1338$ & & & & & & \\
\hline Absorbed & $v(\mathrm{ONO})$ & 1703- & 1680 & & 1690 & 1683 & & 2,9 \\
\hline \multirow[t]{3}{*}{$\mathrm{NO}_{2}$} & & 1693, & & & \multirow[t]{3}{*}{1679} & & & \\
\hline & & 1689- & & & & & & \\
\hline & & 1678 & & & & & & \\
\hline
\end{tabular}




\begin{tabular}{|c|c|c|c|c|c|c|c|c|}
\hline Adsorbed & & 1749 & & & & 1710 & 1748 & 1,10 \\
\hline \multirow[t]{8}{*}{$\mathrm{N}_{2} \mathrm{O}_{4}$} & & 1734 & & & & 1360 & 1262 & \\
\hline & & 1717 & & & & 1273 & 750 & \\
\hline & $v(\mathrm{OH})$ & 3739 & 3745 & & 3286 & 3401 & $3780-$ & 1,11 \\
\hline & & & - & & & & 2990 & \\
\hline & & & 3730 & & & & & \\
\hline & & & 3251 & & & & & \\
\hline & $\delta(\mathrm{HOH})$ & $1630 \pm$ & & & 1643 & 1645 & 1630 & $2,7,12$ \\
\hline & & 15 & & & & & \pm 15 & \\
\hline Surface & & 3208 & & & & & 3208 & 13 \\
\hline adsorbed & & & & & & & 3449 & \\
\hline \multicolumn{9}{|l|}{ water } \\
\hline Isolated & & $3733-$ & & & & & $3733-$ & 14 \\
\hline hydroxyl & & 3691 & & & & & 3691 & \\
\hline bridged & & 3672 & & & & & & 4,15 \\
\hline hydroxyl & & 3642 & & & & & & \\
\hline hydrogen- & & $3616-$ & & & & & & 9,14 \\
\hline bonded & & 3100 & & & & & & \\
\hline Acidic & & $3700-$ & & & & & & 9 \\
\hline \multirow[t]{3}{*}{ hydroxyl } & & 3300 & & & & & & \\
\hline & $v^{a s}\left(\mathrm{CO}_{3}^{2-}\right)$ & 1472 & & 878 & & & $1470-$ & 1,16 \\
\hline & & 1464 & & & & & 1410 & \\
\hline
\end{tabular}


${ }^{\text {a }}$ Several different abbreviations are used: $\sim$, bands assignment does not involve mineral in cited literature; $v^{s}$, symmetrical stretching vibration; $v^{a s}$, antisymmetric stretching vibration; $\delta$, bending or deformation; $v_{3, \text { high }}$, the higher vibration of the double degenerated asymmetric stretch; $v_{3, \text { low }}$, the lower vibration of the double degenerated asymmetric stretch; /, This band is overlapped by many vibrations resulting the assignment is not sure.

Table S4. Assignment of surface species produced on Proxy1 following the adsorption of $\mathrm{NO}_{2}$ at $296 \mathrm{~K}$.

\begin{tabular}{ll}
\hline Surface species & Wavenumber $\left(\mathrm{cm}^{-1}\right)$ \\
\hline monodentate nitrate & $1558,1541,1522,1506$ \\
bidentate nitrate & 1576,1594 \\
bridged nitrate & $1678-1659,1636,1622,1616$ \\
partially solvated nitrate & $1489,1456,1429,1418$ \\
solvated nitrate & $1448,1435,1396,1362,1354$ \\
Nitrite & 1387,1373 \\
\hline
\end{tabular}




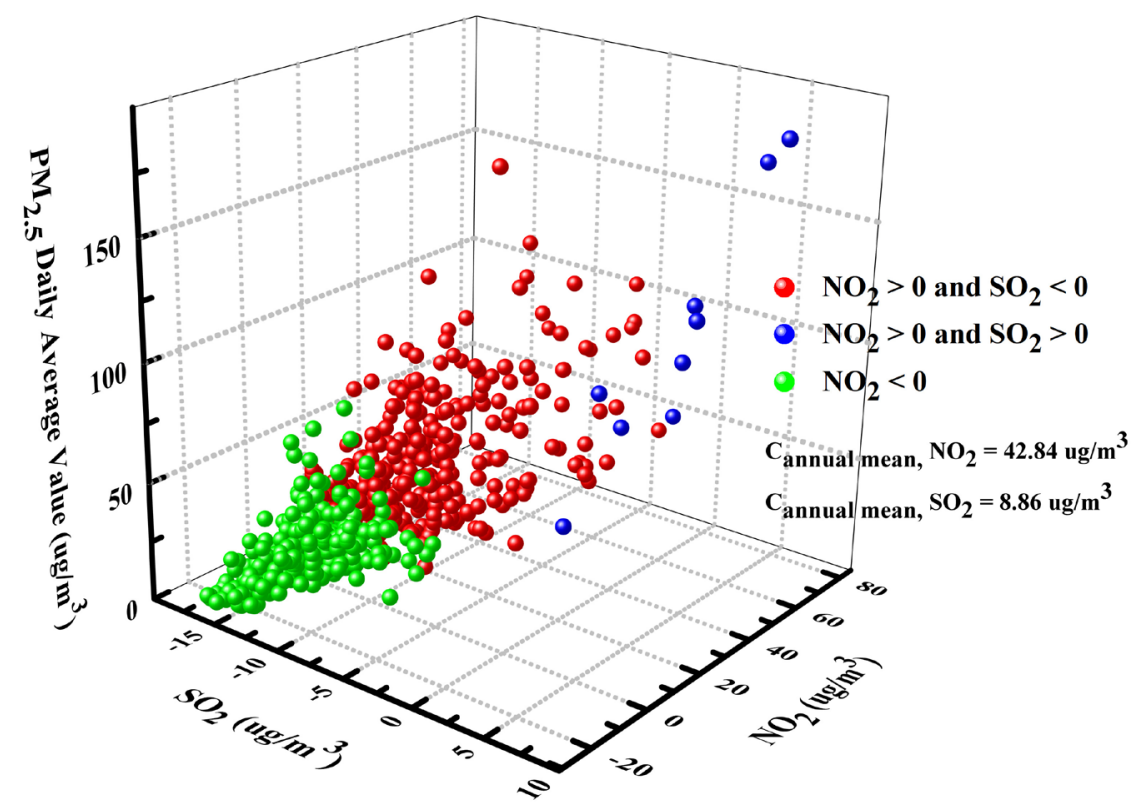

Figure S1. The $\mathrm{PM}_{2.5}$ daily average concentration and the corresponding $\mathrm{NO}_{2}, \mathrm{SO}_{2}$ daily average concentration after deducting the Level 1 standard concentration of the Chinese National Ambient Air Quality Standard, i.e. $\mathrm{SO}_{2}=20 \mu \mathrm{g} / \mathrm{m}^{3}, \mathrm{NO}_{2}=40 \mu \mathrm{g} / \mathrm{m}^{3}$, among 699 days in Shanghai (2017/10/1 2019/5/29 and 2019/9/14 to 2019/12/19, data from http://sthj.sh.gov.cn/). Green, red and blue balls represent the day when the $\mathrm{NO}_{2}$ concentration met, $\mathrm{NO}_{2}$ concentration didn't meet but $\mathrm{SO}_{2}$ met and both $\mathrm{NO}_{2}$ and $\mathrm{SO}_{2}$ didn't met the standard, respectively. It shows that days (344 days) when the concentration of $\mathrm{NO}_{2}$ didn't meet the Level 1 standard were far more than days (10 days) when $\mathrm{SO}_{2}$ didn't meet the standard. 

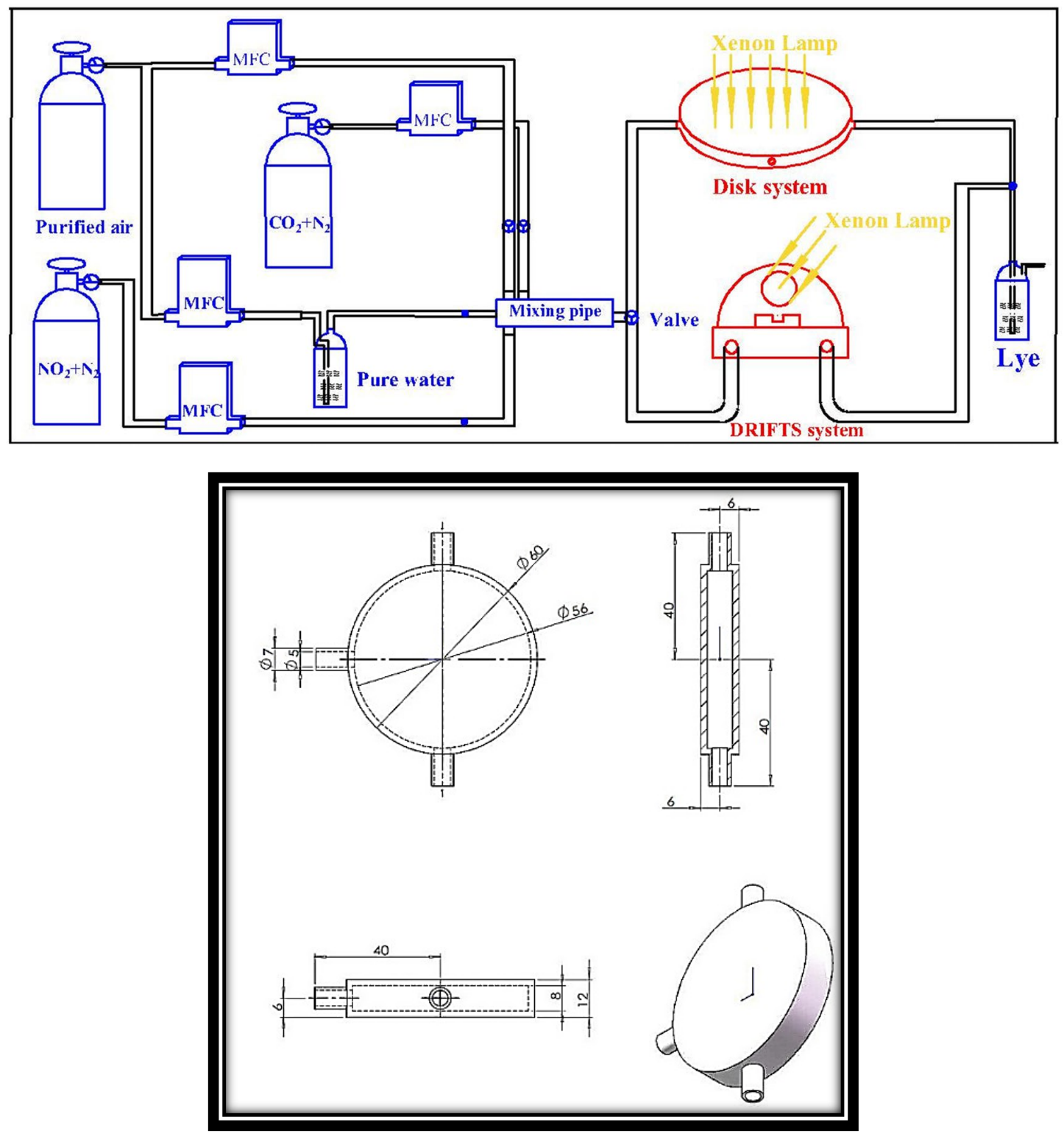

Figure S2. Sketch drawing of two reaction system used in this study (Black, blue, yellow and red represent the gas path, equipment, light source and reaction chamber, respectively). The lower draw shows the disk chamber designed. 


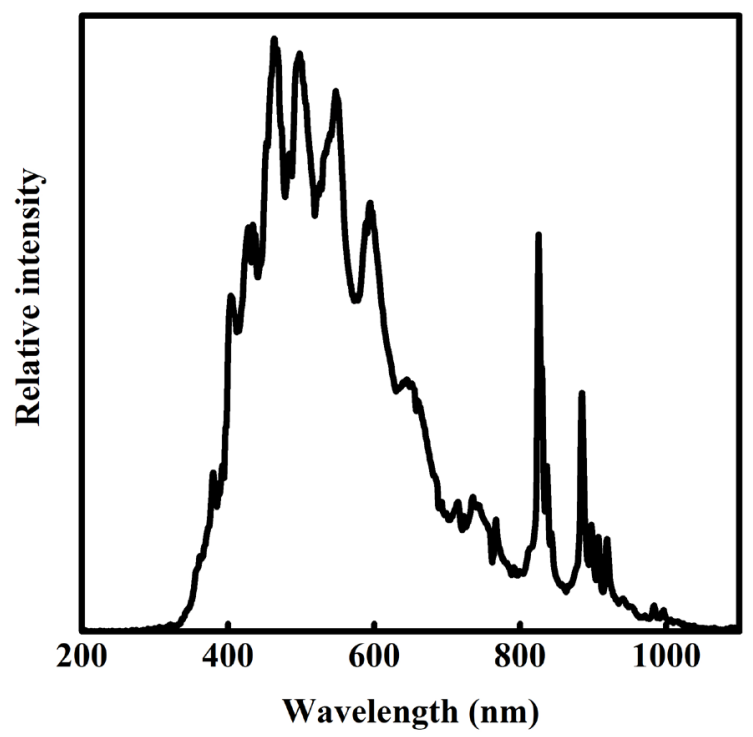

Figure S3. Spectral distribution of the Xenon lamp light measured by a fiber optic spectrometer (AULTT-P4000, Beijing Ceaulight Co., LTD, China).

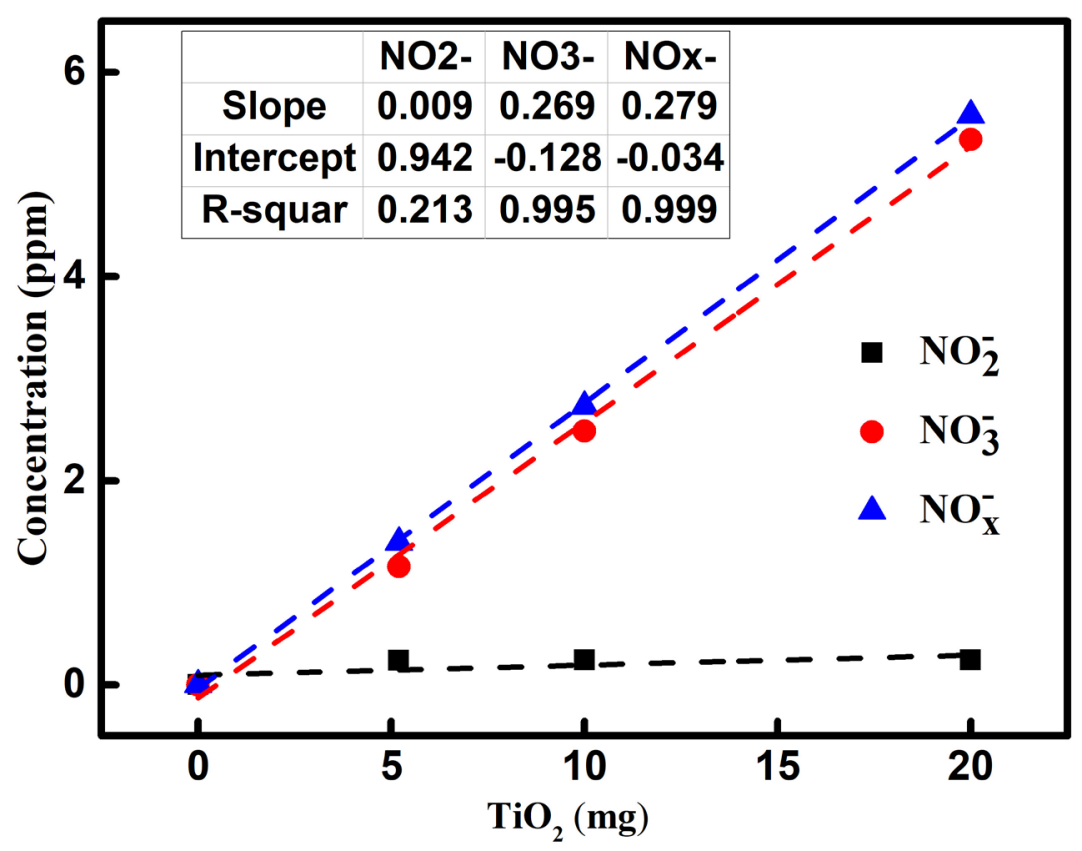

Figure S4. The linear relationship between the ion concentration generated on the surface of $\mathrm{TiO}_{2}$ in the disk reaction chamber and mass used for the IC test. 


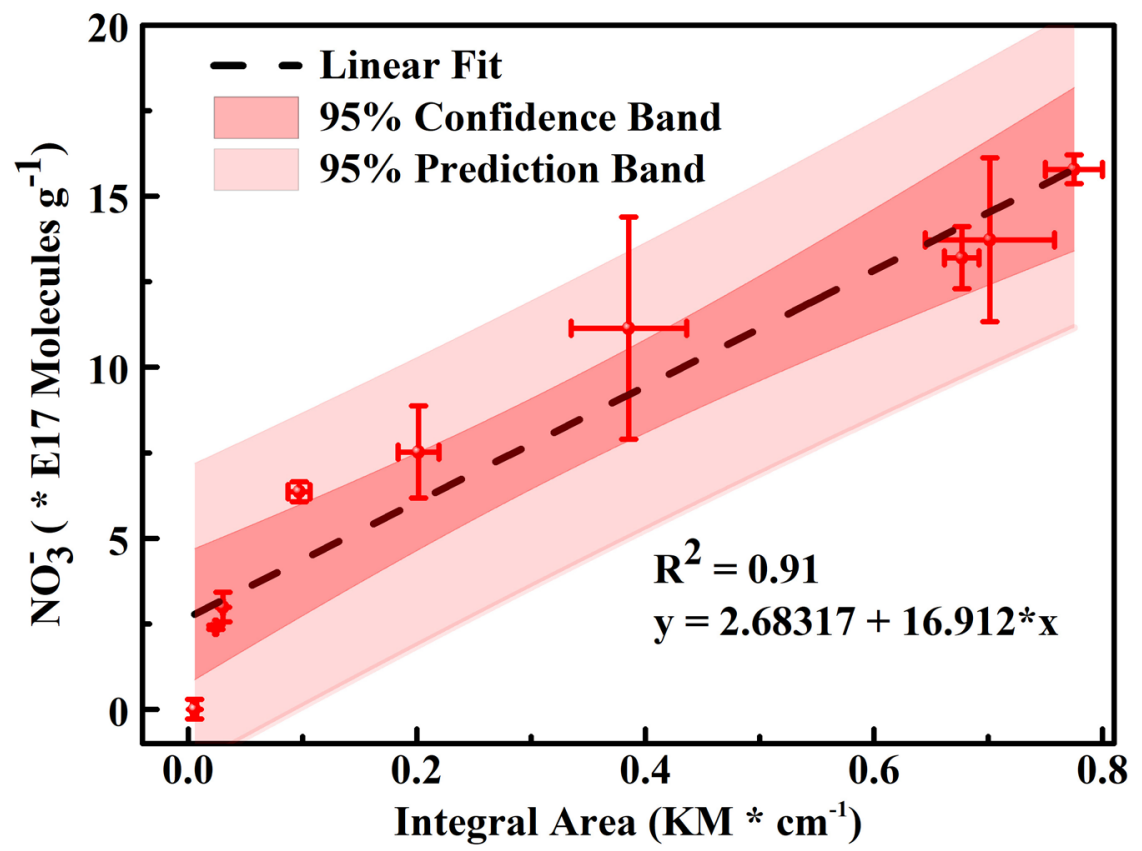

Figure S5. Calibration plot for Conversion-factor of molecules of $\mathrm{NO}_{3}^{-}$normalized by particle quality used in infrared experiments versus corresponding integrated area of KM with 95\% confidence/prediction interval. The fitted curve doesn't cross $(0,0)$ point due to the detection limit of IC, i.e., the very low concentration measured by IC cannot be well distinguished from the background concentration. 


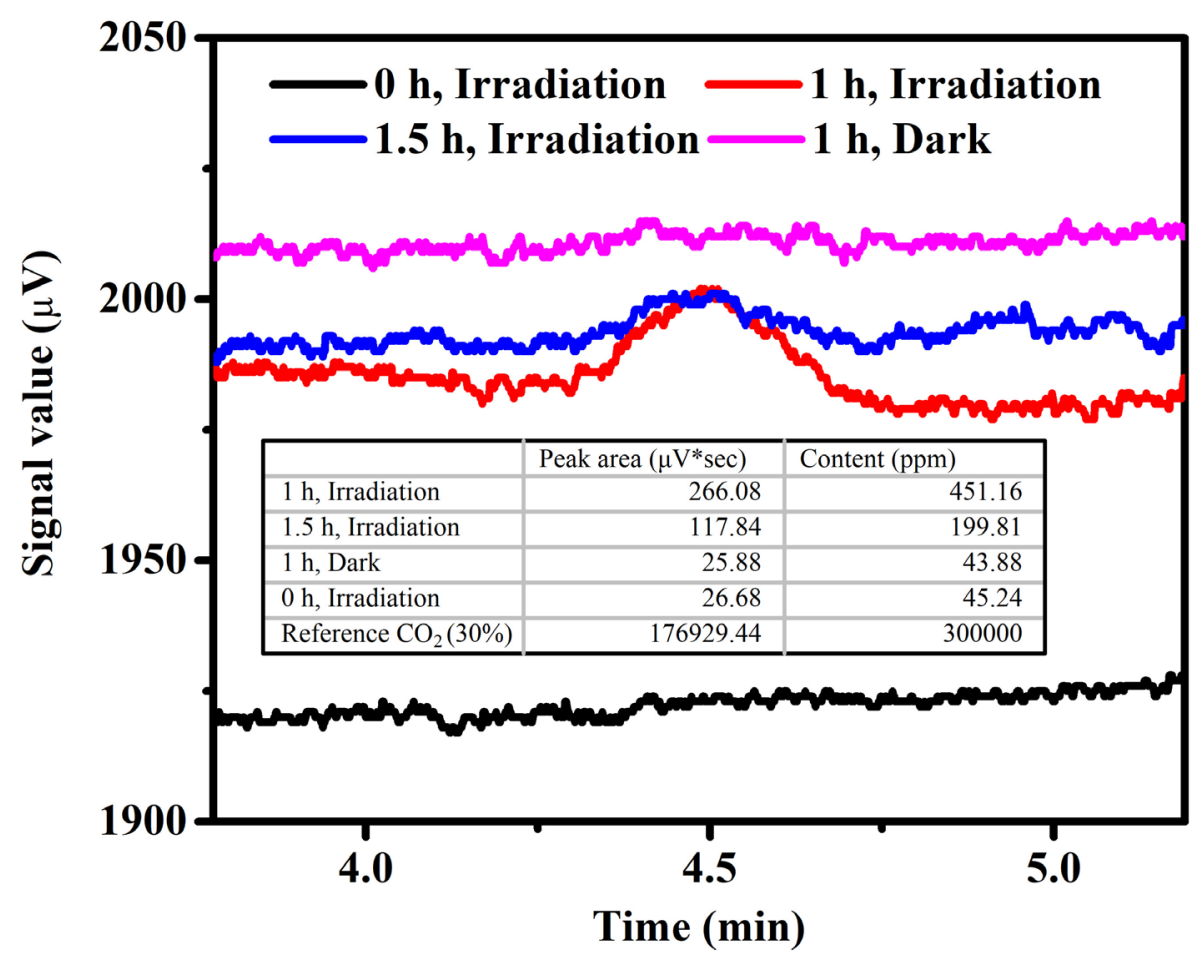

Figure S6. The gas chromatograph (GC) signal of $\mathrm{CO}_{2}$. The inserted table shows that the gas sample contained about $405 \mathrm{ppm}$ and $155 \mathrm{ppm}$ of $\mathrm{CO}_{2}$ after particles $(50 \%$ $\mathrm{CaCO}_{3}+50 \% \mathrm{TiO}_{2}$ ) exposed to irradiation for $1 \mathrm{~h}$ and $1.5 \mathrm{~h}$ respectively, while no $\mathrm{CO}_{2}$ was produced under the dark reaction. The lower content of $\mathrm{CO}_{2}$ at $1.5 \mathrm{~h}$ may be related to the adsorption by particles. The details are as follows: The airtight disk reaction chamber was filled with $30 \mathrm{mg}$ particles $\left(50 \% \mathrm{CaCO}_{3}+50 \% \mathrm{TiO}_{2}\right)$ and then filled with $10 \mathrm{~mL}$ pure air $(15 \% \mathrm{RH})$ after $120 \mathrm{~mL} / \mathrm{min}_{2}$ purge. $0.5 \mathrm{~mL}$ of gas was sampled to measure the GC signal value after irradiation for $0 \mathrm{~h}$ (black line), $1 \mathrm{~h}$ (red line), $1.5 \mathrm{~h}$ (blue line) and after $1 \mathrm{~h}$ under dark reaction (pink line). The retention time and half peak width of standard gas $\mathrm{CO}_{2}(30 \%)$ are $4.5 \mathrm{~min}$ and $0.3 \mathrm{~min}$, respectively. 


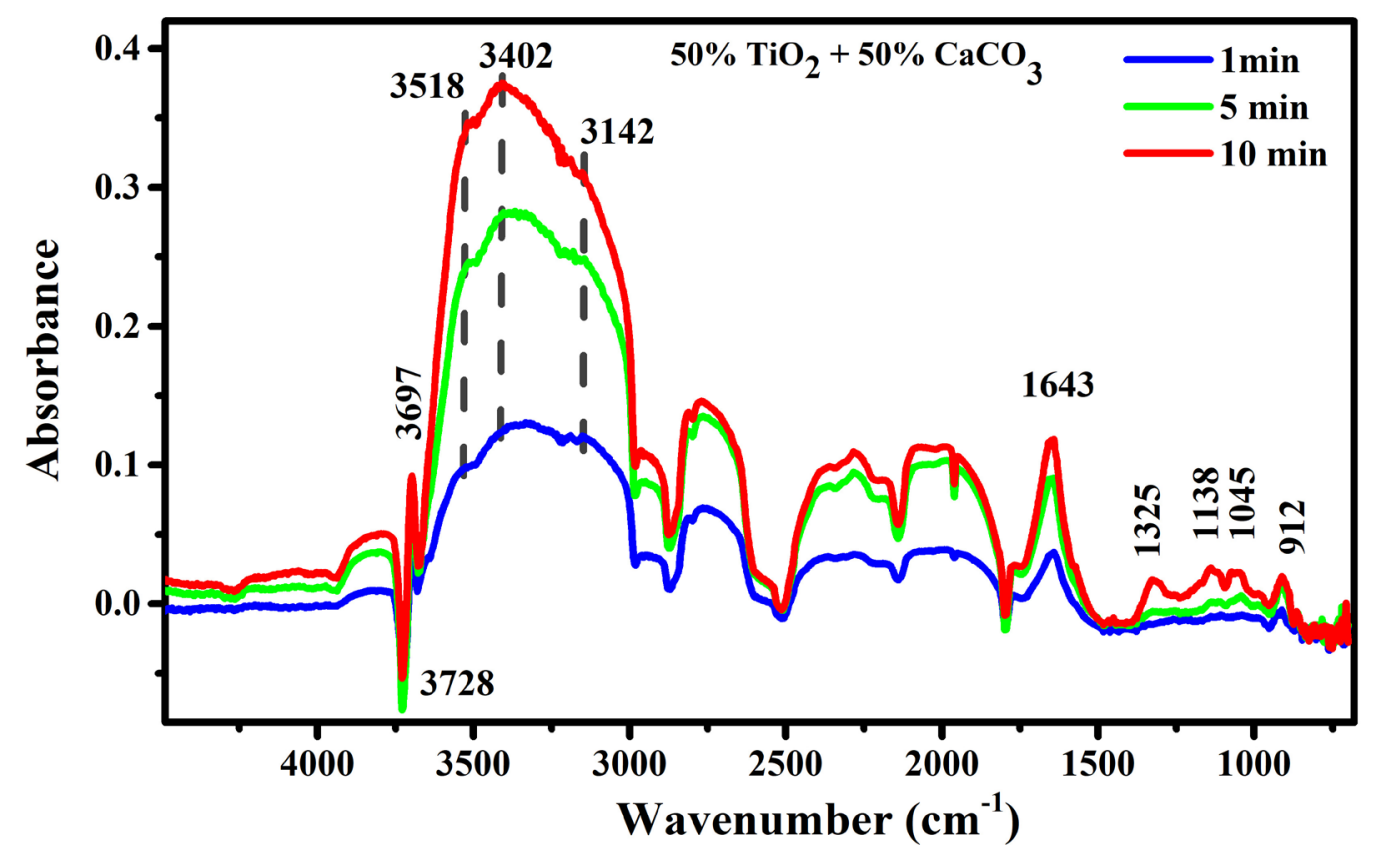

Figure S7. DRIFTS spectra recorded of $50 \% \mathrm{TiO}_{2}+50 \% \mathrm{CaCO}_{3}$ following exposure to $\mathrm{NO}_{2}$ for $60 \mathrm{~min}$.

Negative bands at $3728 \mathrm{~cm}^{-1}$ are considered as the consumption of isolated hydroxyl groups. ${ }^{4}$ The growth band at $3697 \mathrm{~cm}^{-1}$ can be ascribed to bridged hydroxyl groups. ${ }^{15}$ The strong absorption bands with peaks at $3518 \mathrm{~cm}^{-1}$ can be attributed to $v(\mathrm{OH})$ of hydrogen-bonded $\mathrm{OH}$ groups of acids. ${ }^{9}$ According to Walrafen et al, the peaks at 3402 and $3142 \mathrm{~cm}^{-1}$ are mainly assigned to hydrogen-bonded species. ${ }^{17}$ As can be seen in Figure S7, hydrogen-bonded and acidic $\mathrm{OH}$ groups were formed on the surface of $\mathrm{CaCO}_{3} / \mathrm{TiO}_{2}$. The bridged nitrate absorbs at $1643 \mathrm{~cm}^{-1}$ on $\mathrm{CaCO}_{3} / \mathrm{TiO}_{2}$, which is found to be the main adsorbed nitrate species on $\mathrm{CaCO}_{3} / \mathrm{TiO}_{2}$. Notably, the band of $\delta(\mathrm{HOH})$ $\left(1630 \pm 15 \mathrm{~cm}^{-1}\right)$ can superimpose this band. Bidentate nitrate exhibits $v(\mathrm{O}-\mathrm{O})$ vibrations at $912 \mathrm{~cm}^{-1} .{ }^{8}$ Water solvated nitrate absorbs at $1325 \mathrm{~cm}^{-1}$ and nitrate ions absorb at $1045 \mathrm{~cm}^{-1}\left(v_{1}\right)$. What's special is the band at $1138 \mathrm{~cm}^{-1}$ assigned to out-ofplane bending vibration of protonated hydrated nitric acid, i.e. $\left[\mathrm{OH}_{3}\right]^{+} \mathrm{NO}_{3}^{-8}$, which 
indicates an acidic surface of $\mathrm{CaCO}_{3} / \mathrm{TiO}_{2}$. Carbonyl compounds absorb strongly in the range of $1950-1697 \mathrm{~cm}^{-1} .8,18$ These bands correspond to an increase of surface dissolved carbonate.
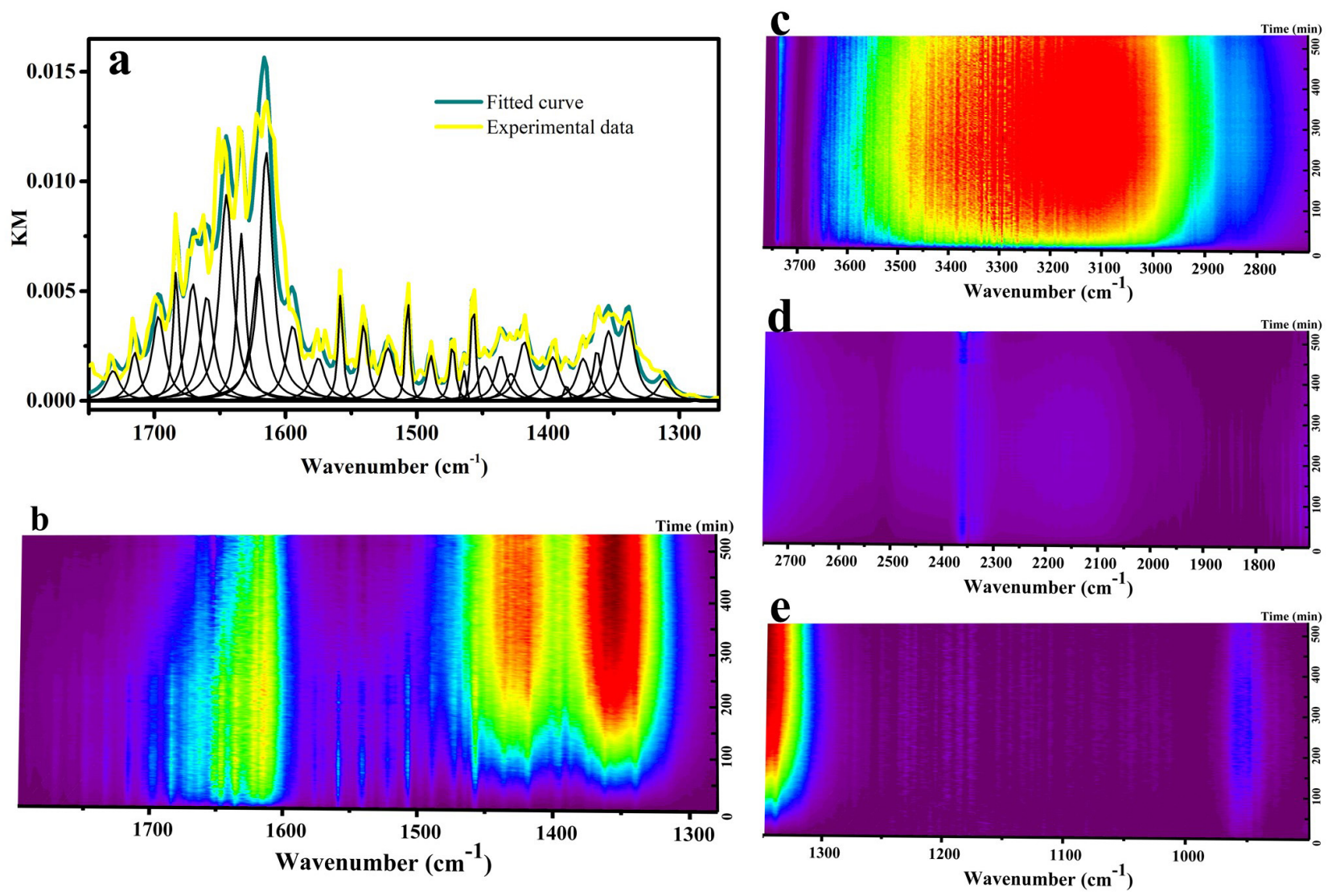

Figure S8. DRIFTS spectra recorded of Proxy1 exposed to $5 \mathrm{ppm} \mathrm{NO}_{2}$ after a reaction time of 530 min. (a) Lorenz and Gaussian functions were used to fit the vibrations from 1750 to $1250 \mathrm{~cm}^{-1}$. The cyan line is the total fitting curve and the yellow line is the experimental data at 40 min. (b - e) Top view of the three-dimension DRIFTS spectra shown in Figure 2b from (b) 1800 to $900 \mathrm{~cm}^{-1}$, (c) 3770 to $2700 \mathrm{~cm}^{-1}$, (d) 2750 to 1700 $\mathrm{cm}^{-1}$ and (e) 1350 to $900 \mathrm{~cm}^{-1}$. 


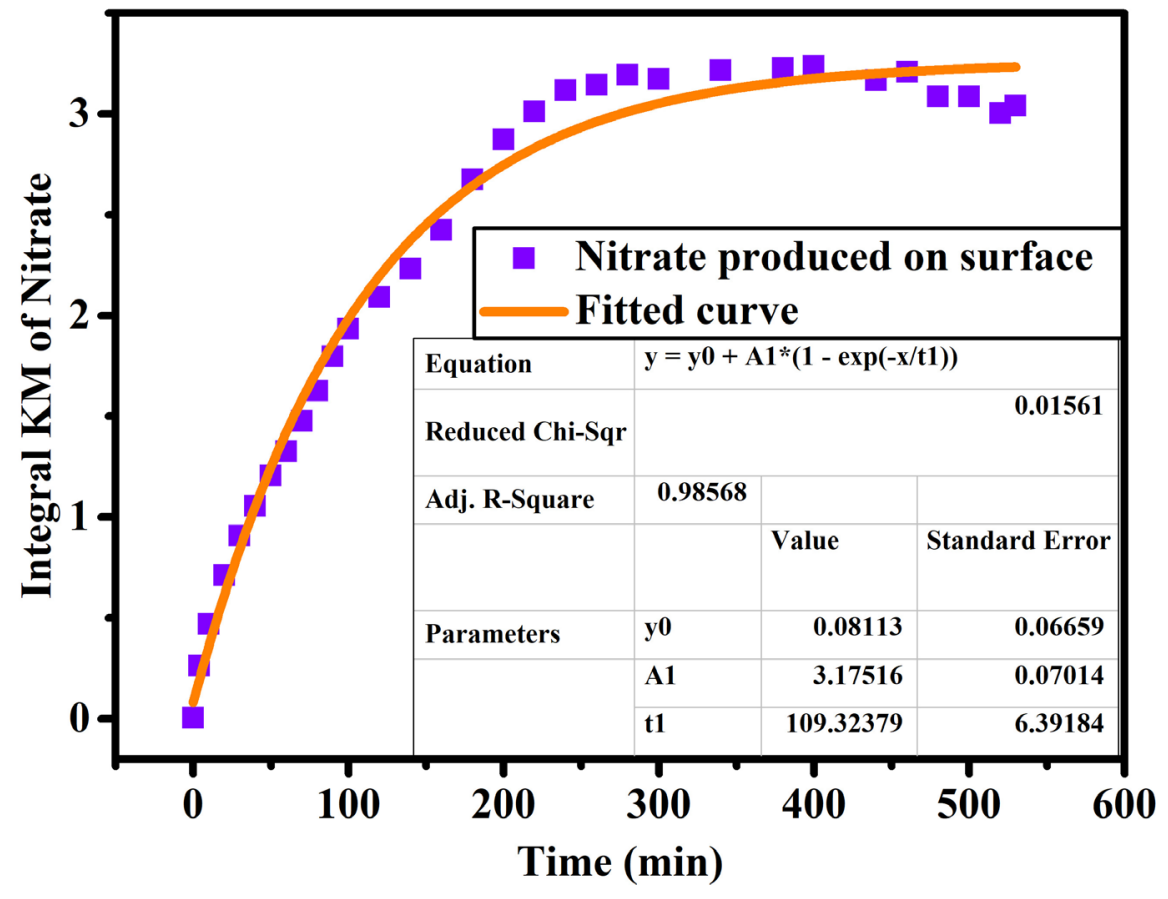

Figure S9. Calibration plot of surface nitrate (adsorbed, solvated) produced on mineral dust proxy $\left(5 \% \mathrm{TiO}_{2}+5 \% \mathrm{CaCO}_{3}+80 \% \mathrm{SiO}_{2}+10 \% \mathrm{Al}_{2} \mathrm{O}_{3}\right)$ versus time of reaction. Filled squares are integrated $\mathrm{KM}$ of surface nitrate including adsorbed and solvated forms. The inset plate shows the regression parameters.

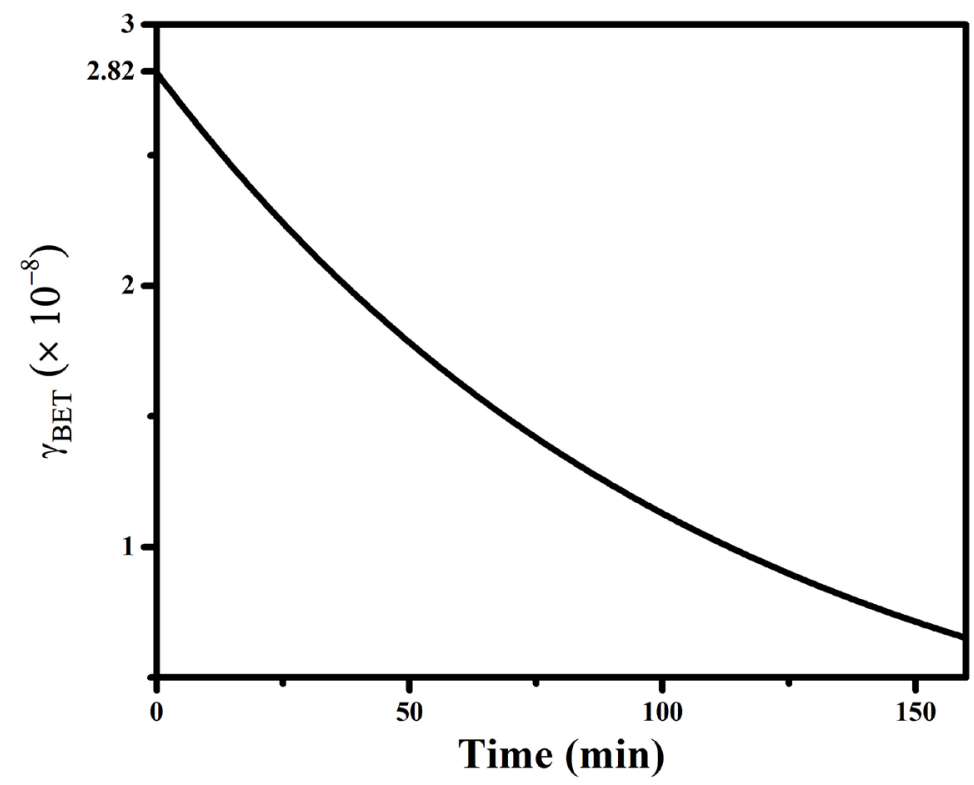

Figure S10. The time-dependent uptake coefficient $\left(\gamma_{\mathrm{BET}}\right)$ of $\mathrm{NO}_{2}$ uptake on Proxy1 under light condition $\left(15 \mathrm{~mW} / \mathrm{cm}^{2}\right)$ at $298 \mathrm{~K}$. 


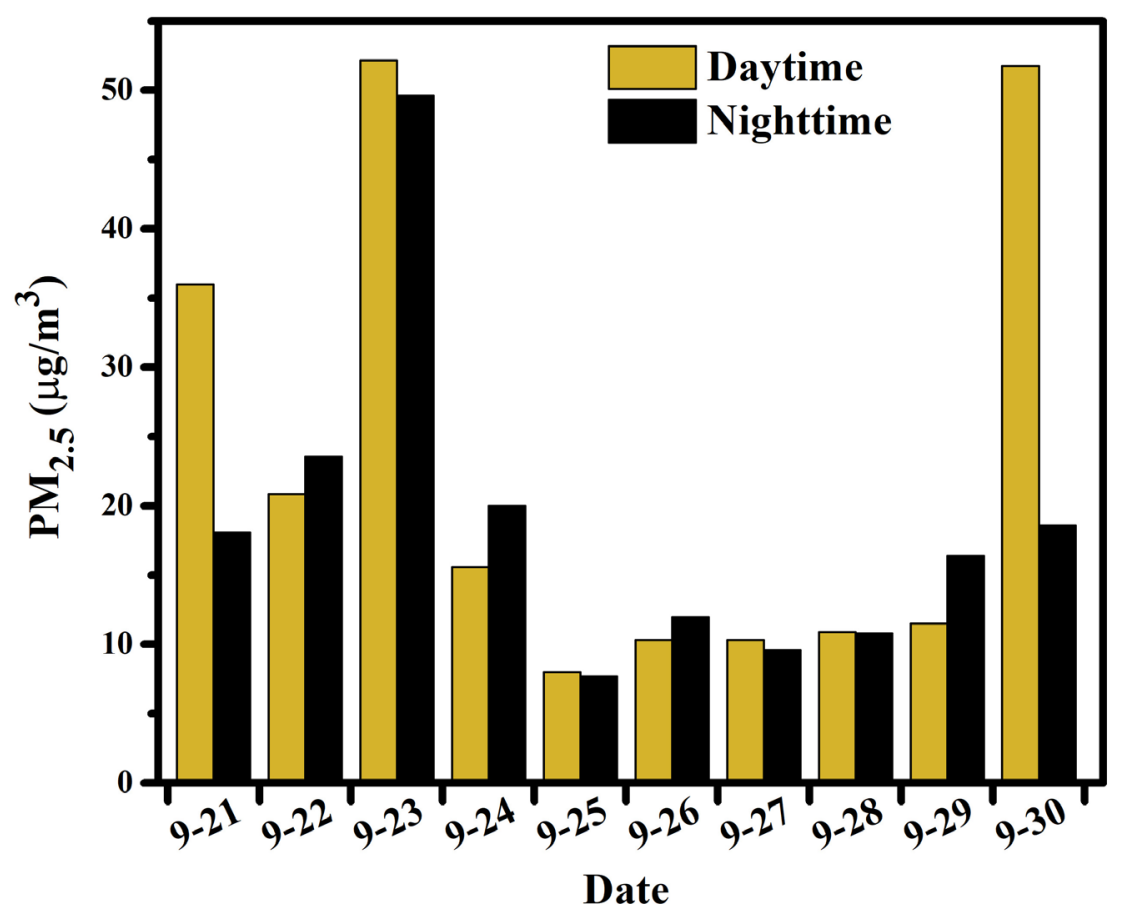

Figure S11. Hourly average $\mathrm{PM}_{2.5}$ concentration at the daytime (dark yellow column, $7: 00-19: 00$ ) and corresponding nighttime (black column, 19:00 - 7:00) of the sampling date: 22 September 2018 to 29 September 2018. Data from China Environmental Monitoring Center.
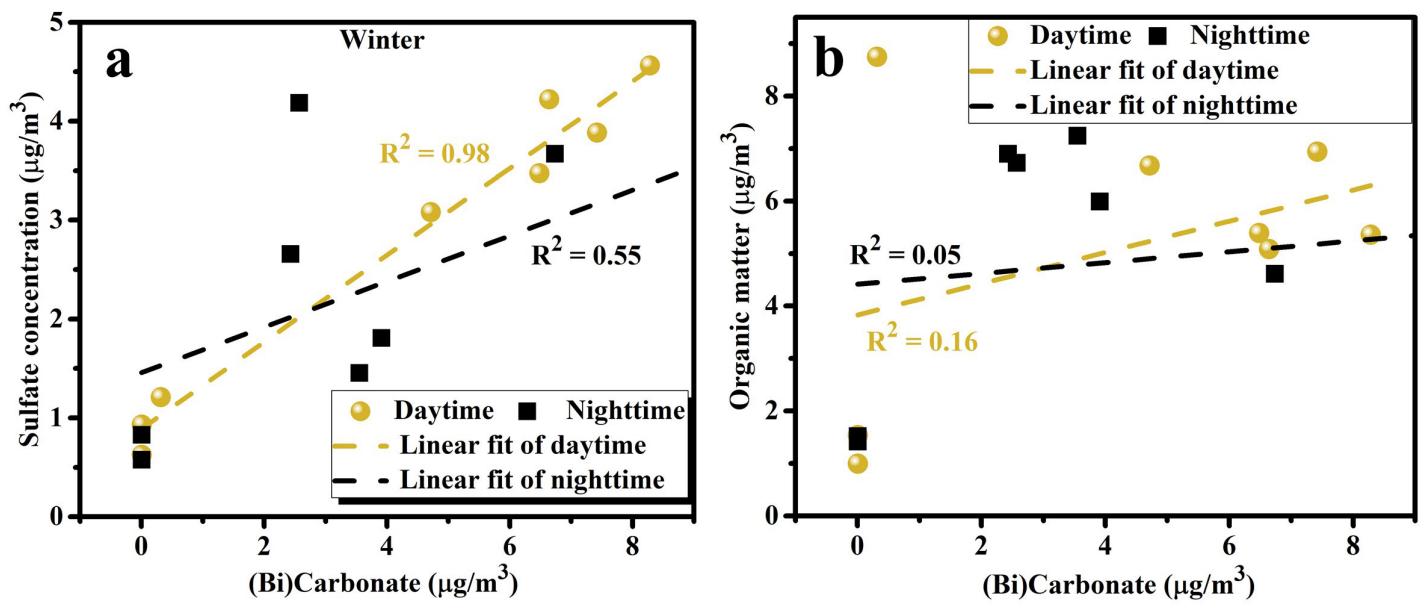

Figure S12. Correlation at daytime (yellow ball) and nighttime (black square) between the sulfate/organic matter and (bi)carbonate concentration in winter. Here the organic 
matter means organic acid ions in the atmosphere detected by IC (including formate, acetate, lactate and oxalate).
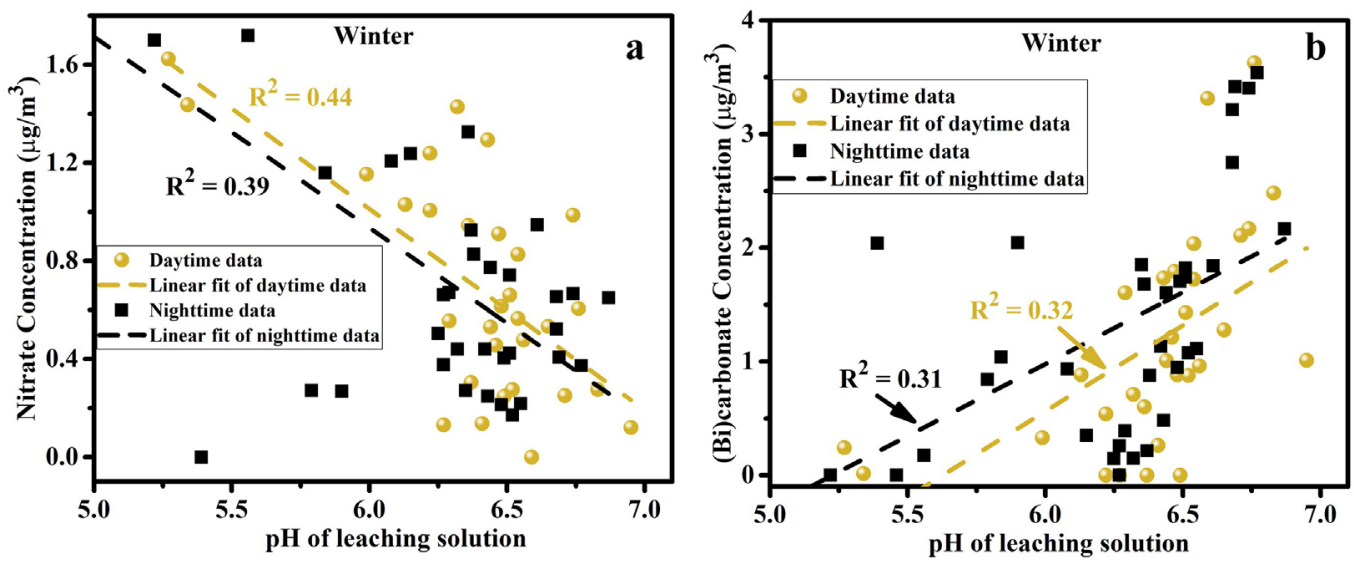

Figure S13. Correlation at daytime (yellow ball) and nighttime (black square) between the $\mathrm{pH}$ and (a) the nitrate or (b) (bi)carbonate concentration of the leaching solution of winter particles sample $(>2 \mu \mathrm{m})$. The R-square of the linear fit of corresponding data was also shown. 

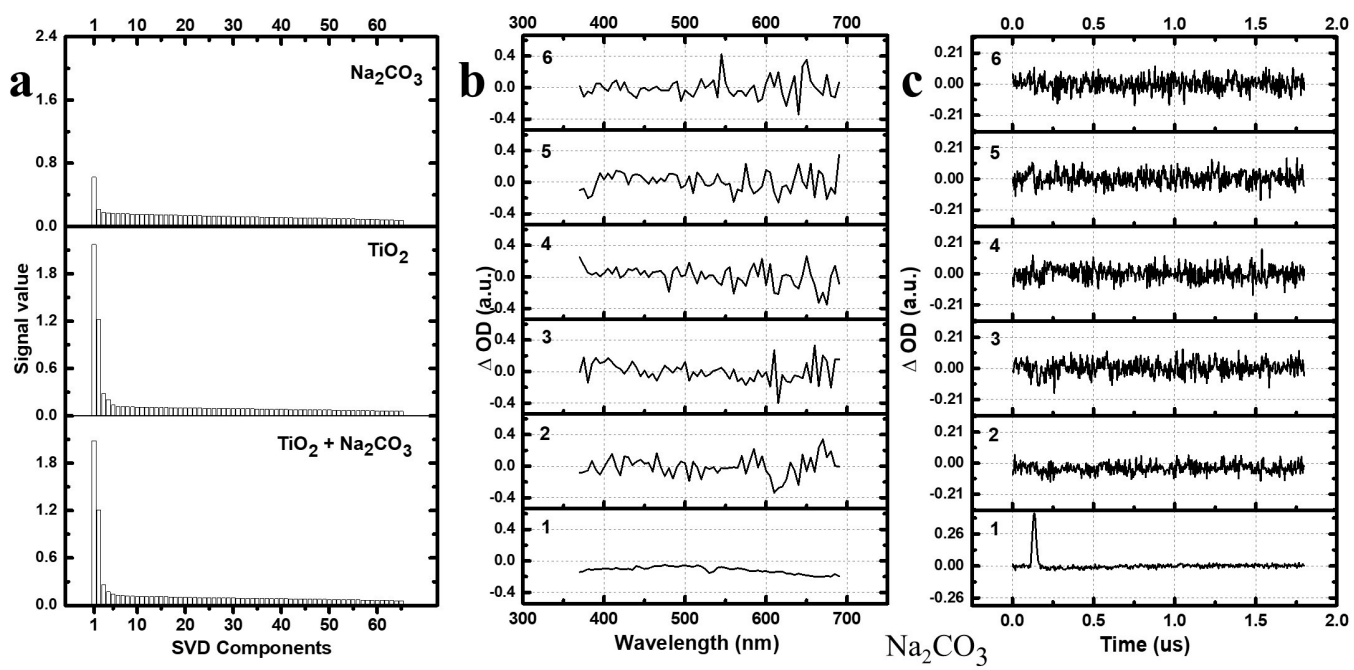

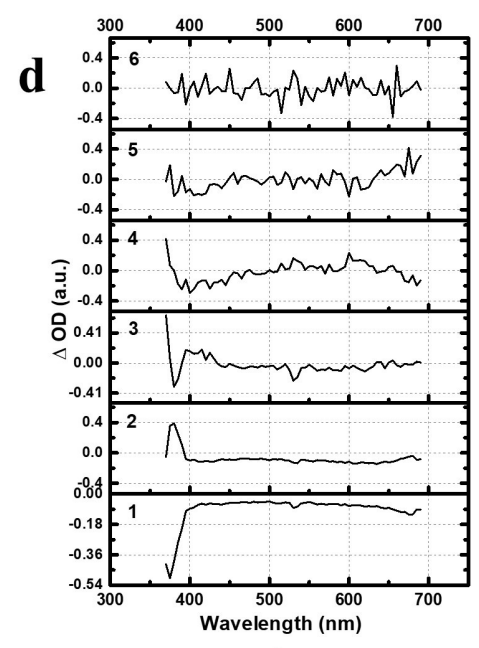

$\mathrm{TiO}_{2}$

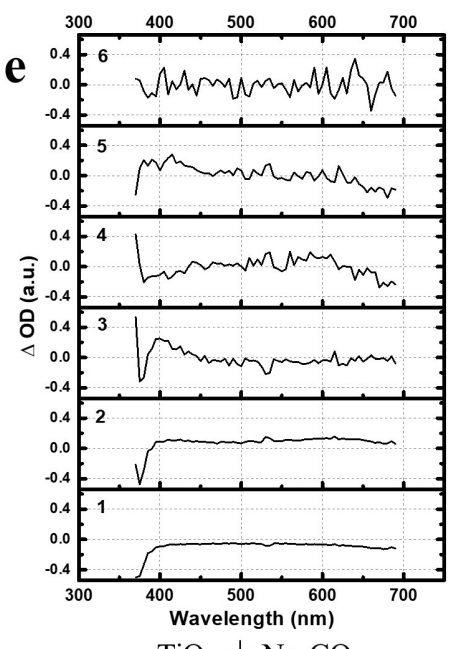

$\mathrm{TiO}_{2}+\mathrm{Na}_{2} \mathrm{CO}_{3}$

Figure S14. (a) shows the singular value for these three TA spectra. The six SVD wavelength-dependent basis vectors (U) and six time-dependent basis vectors (V) obtained from TA spectra matrix of (b, c) $\mathrm{Na}_{2} \mathrm{CO}_{3}$, (d) $\mathrm{TiO}_{2}$ and (e) $\mathrm{TiO}_{2}+\mathrm{Na}_{2} \mathrm{CO}_{3}$. 

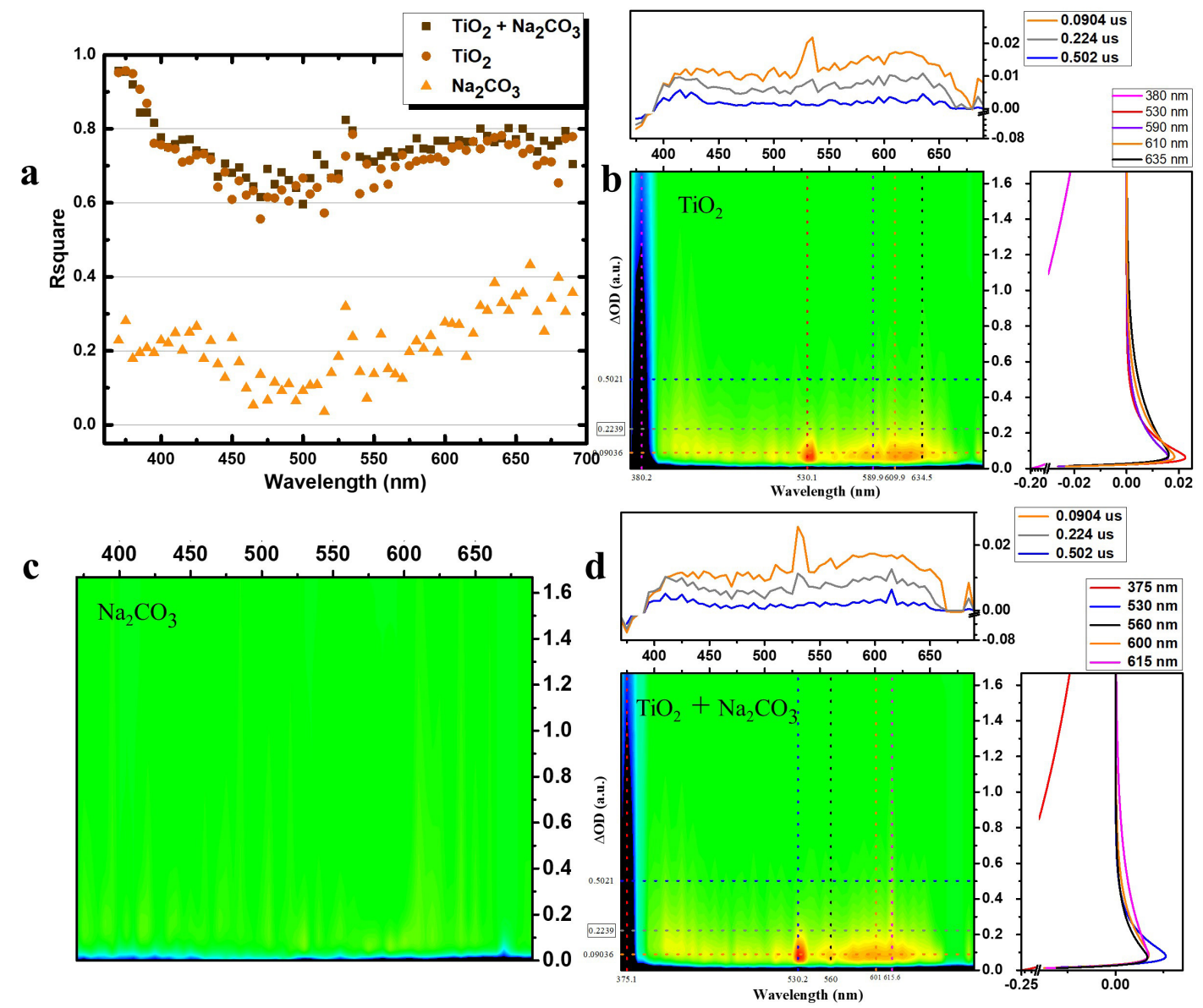

Figure S15. (a) shows the fitted R-square for each spectrum. The biexponential fitted TA spectra of (b) $\mathrm{TiO}_{2}$, (c) $\mathrm{Na}_{2} \mathrm{CO}_{3}$ and (d) $\mathrm{TiO}_{2}+\mathrm{Na}_{2} \mathrm{CO}_{3}$.

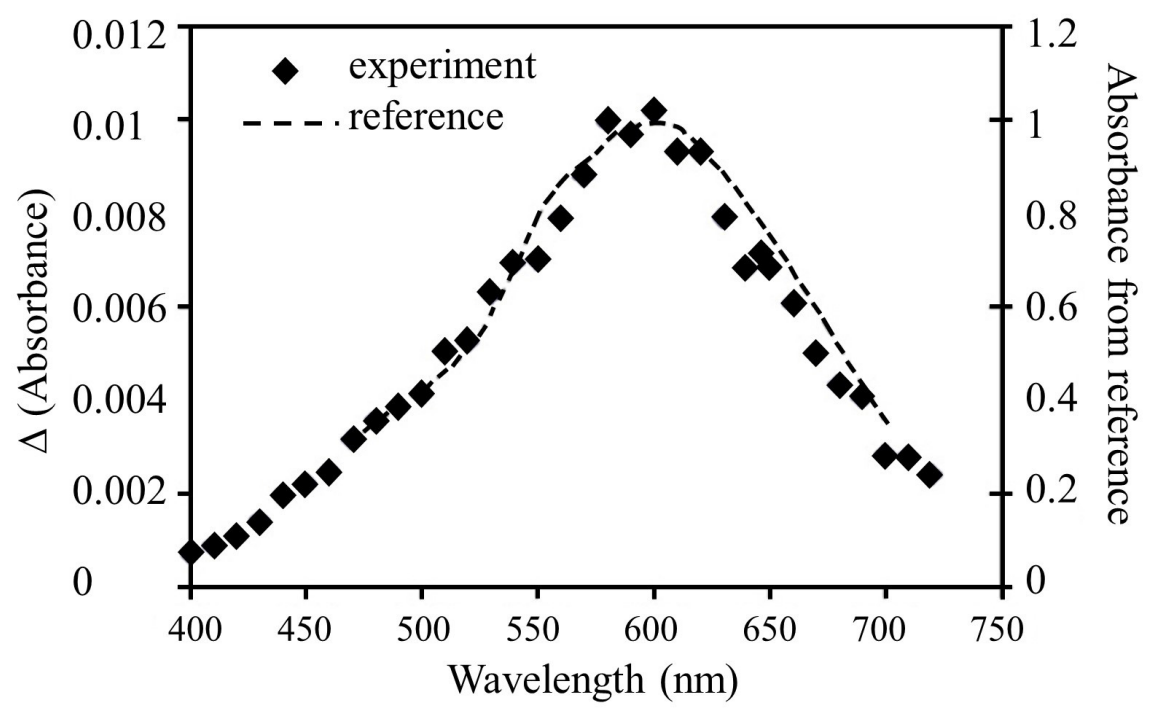

Figure S16. The absorption spectrum of $\mathrm{CO}_{3}^{\bullet-}$ in literature. ${ }^{19,20}$ 


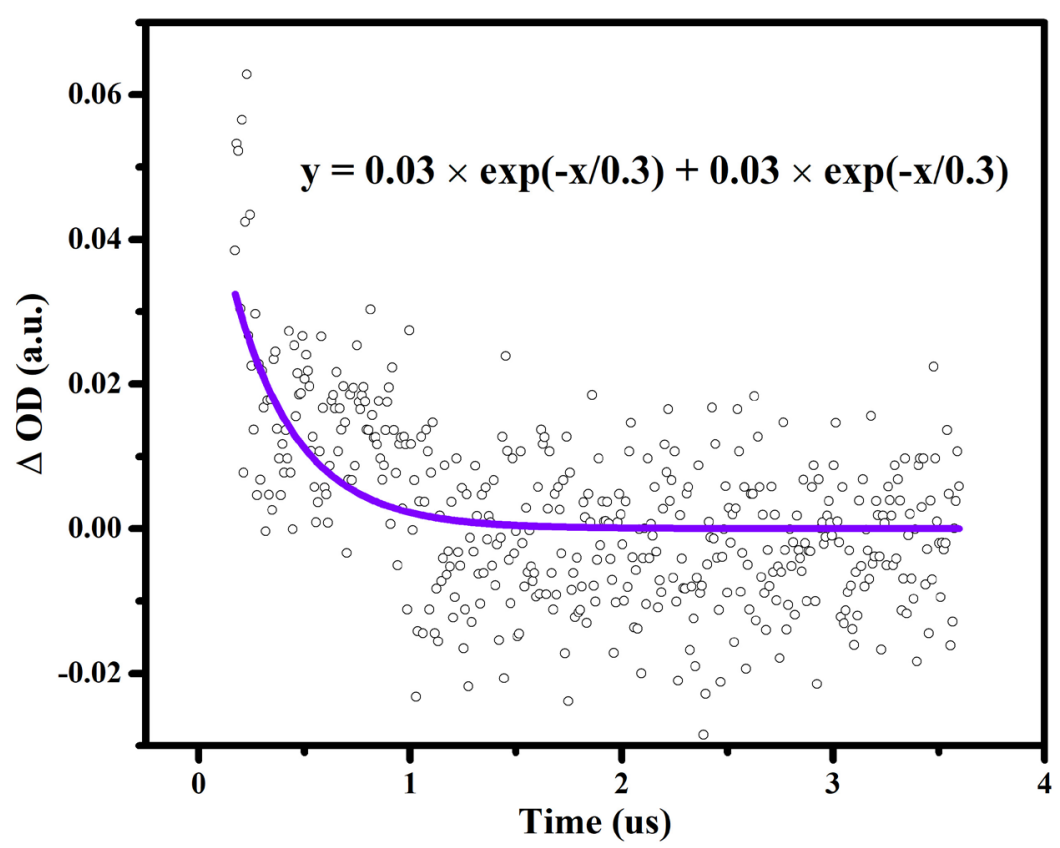

Figure S17. $\mathrm{CO}_{3}^{\bullet-} \mathrm{TA}$ signal in liquid phase. TA spectrum of $10 \mathrm{~g} \mathrm{~L}^{-1} \mathrm{TiO}_{2}$ mixed with $1 \mathrm{M} \mathrm{Na}_{2} \mathrm{CO}_{3}$ at $600 \mathrm{~nm}$. Data has subtracted the TA spectrum of $10 \mathrm{~g} \mathrm{~L}^{-1} \mathrm{TiO}_{2}$. The purple line is the biexponential fitting result.
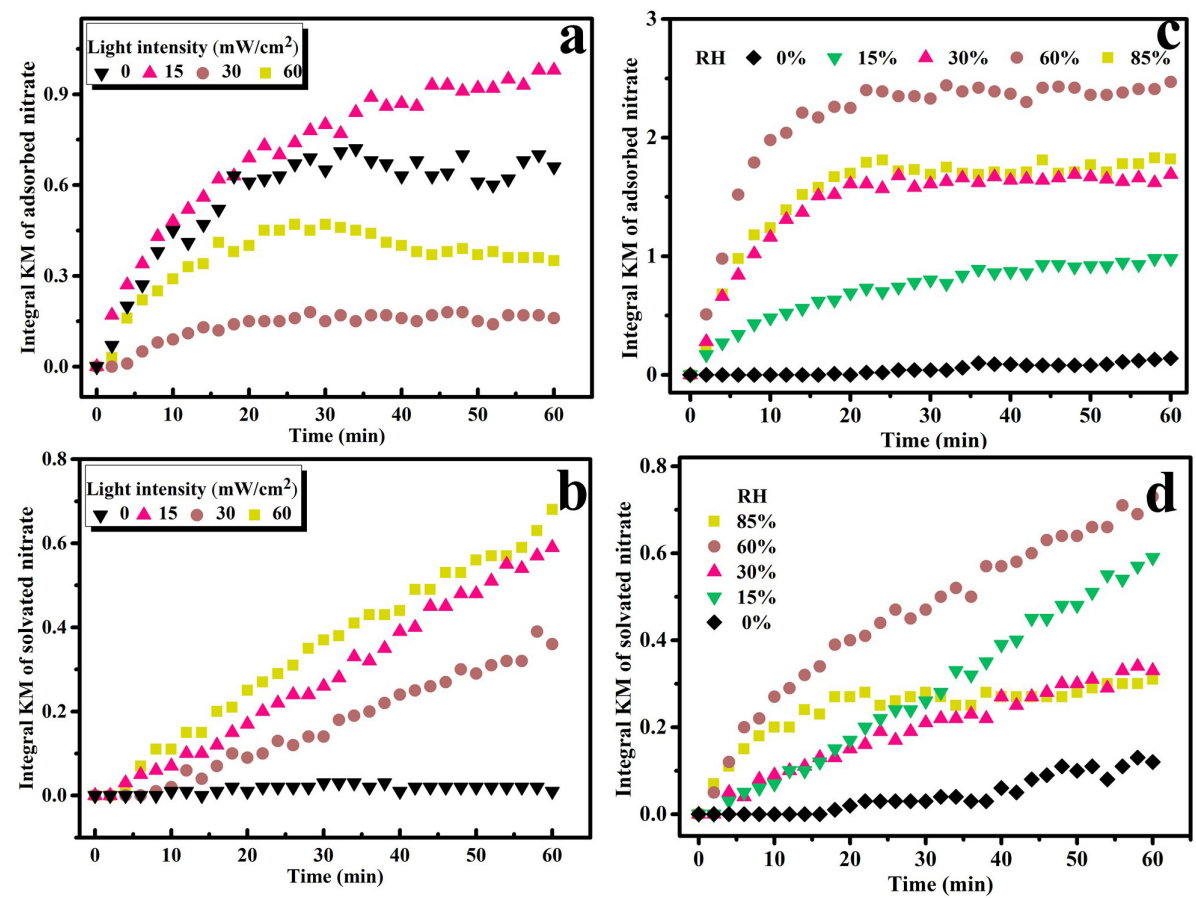

Figure S18. Light intensity and humidity influence to the formation of nitrate on

Proxy1 as a function of reaction time (60 $\mathrm{min})$. Integral $\mathrm{KM}$ of adsorbed (a) and 
solvated (b) nitrate production under $0,15,30$ and $60 \mathrm{~mW} / \mathrm{cm}^{2}$ light intensity and $15 \%$ RH. Integral KM of adsorbed (c) and solvated (d) nitrate production under $0 \%, 15 \%$, $30 \%, 60 \%$ and $85 \% \mathrm{RH}$ and $15 \mathrm{~mW} / \mathrm{cm}^{2}$.

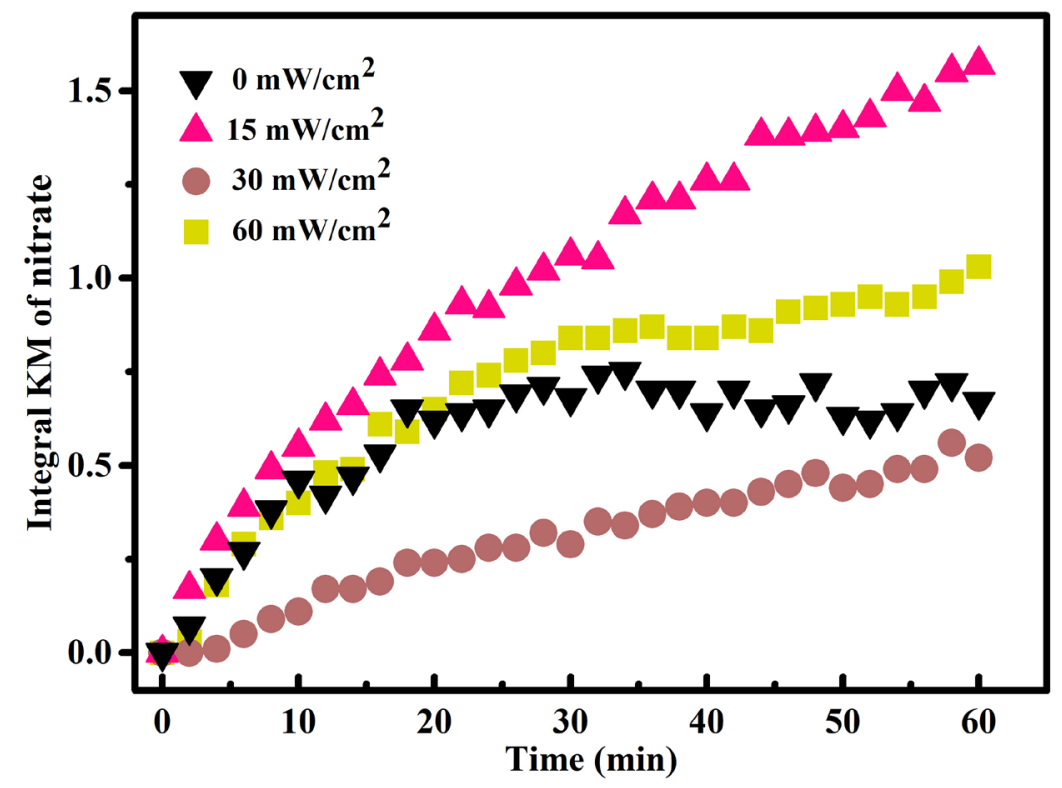

Figure S19. The integral $\mathrm{KM}$ of nitrate production under $0,15,30$ and $60 \mathrm{~mW} / \mathrm{cm}^{2}$ light intensity and $15 \% \mathrm{RH}$ as a function of reaction time (60 $\mathrm{min})$.
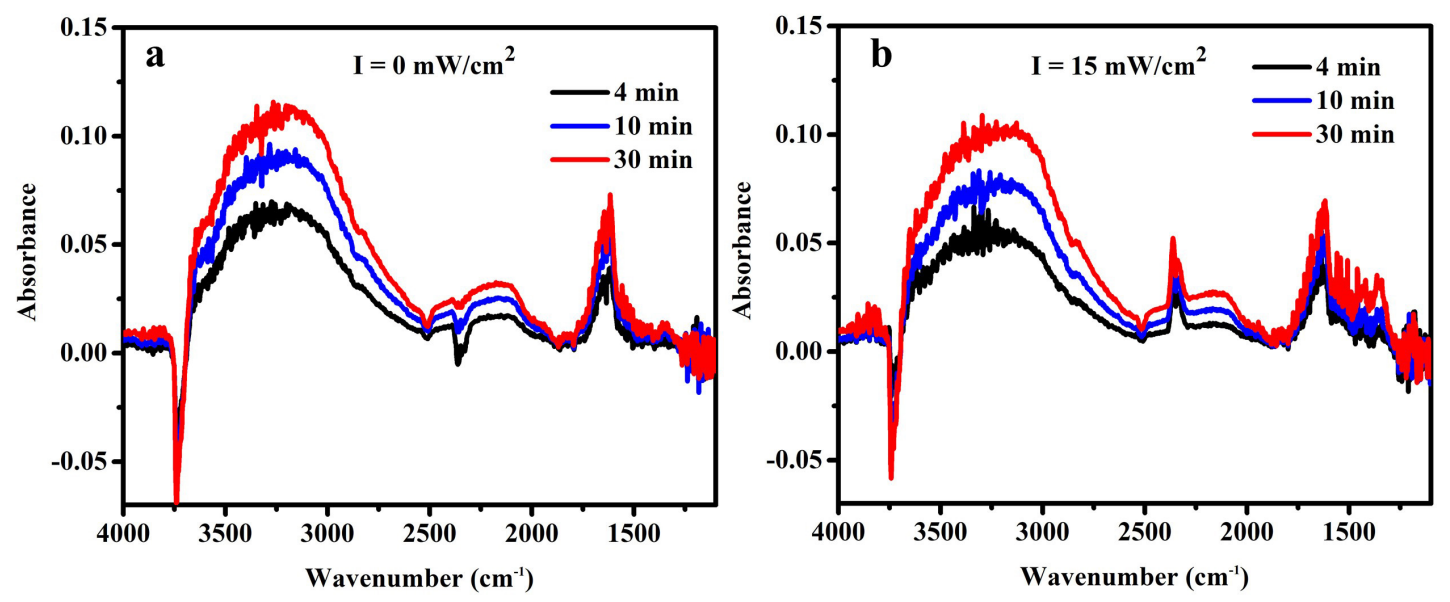

Figure S20. Time-resolved DRIFTS spectra recorded on Proxy1 under (a) 0 and (b) 15 $\mathrm{mW} / \mathrm{cm}^{2}$ light intensity and $15 \% \mathrm{RH}$. 


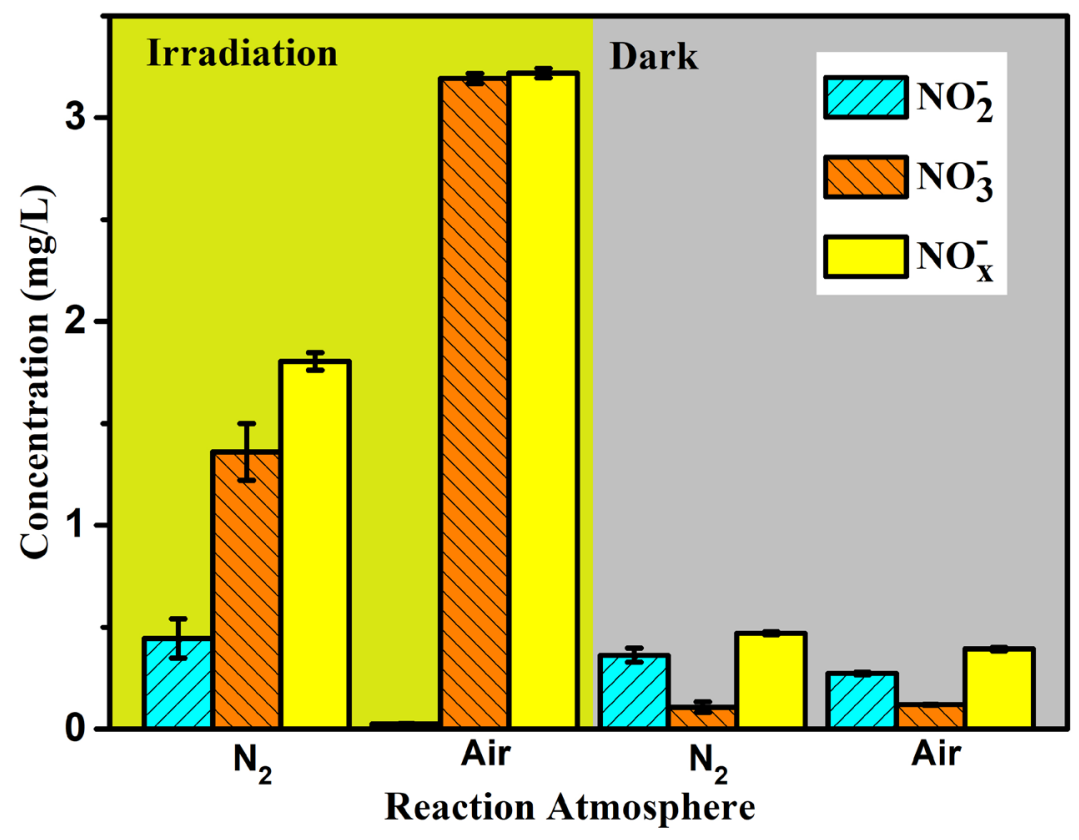

Figure S21. Comparison of $\mathrm{NO}_{2}^{-}$(cyan column), $\mathrm{NO}_{3}^{-}$(orange column) and $\mathrm{NO}_{\mathrm{x}}^{-}$ (yellow column) concentration produced on mineral dust proxy $\left(50 \% \mathrm{TiO}_{2}+50 \%\right.$ $\mathrm{CaCO}_{3}$ ) under different reaction atmosphere and light conditions (reaction time $=30$ $\min )$.

\section{References}

1. Nakamoto, K., Infrared and R aman Spectra of Inorganic and Coordination Compounds. Handbook of Vibrational Spectroscopy 2006.

2. Goodman, A.; Bernard, E.; Grassian, V., Spectroscopic study of nitric acid and water adsorption on oxide particles: Enhanced nitric acid uptake kinetics in the presence of adsorbed water. The Journal of Physical Chemistry A 2001, 105, (26), 6443-6457.

3. Baltrusaitis, J.; Schuttlefield, J.; Jensen, J. H.; Grassian, V. H., FTIR spectroscopy combined with quantum chemical calculations to investigate adsorbed nitrate on Page S28 
aluminium oxide surfaces in the presence and absence of co-adsorbed water. Physical Chemistry Chemical Physics 2007, 9, (36), 4970-4980.

4. Nanayakkara, C. E.; Larish, W. A.; Grassian, V. H., Titanium dioxide nanoparticle surface reactivity with atmospheric gases, $\mathrm{CO}_{2}, \mathrm{SO}_{2}$, and $\mathrm{NO}_{2}$ : Roles of surface hydroxyl groups and adsorbed water in the formation and stability of adsorbed products. The Journal of Physical Chemistry C 2014, 118, (40), 23011-23021.

5. Hadjiivanov, K.; Knözinger, $\mathrm{H} .$, Species formed after $\mathrm{NO}$ adsorption and $\mathrm{NO}+\mathrm{O}_{2}$ co-adsorption on $\mathrm{TiO}_{2}$ : an FTIR spectroscopic study. Physical Chemistry Chemical Physics 2000, 2, (12), 2803-2806.

6. Zondlo, M. A.; Barone, S. B.; Tolbert, M. A., Uptake of $\mathrm{HNO}_{3}$ on ice under upper tropospheric conditions. Geophysical Research Letters 1997, 24, (11), 1391-1394.

7. Al-Hosney, H. A.; Grassian, V. H., Water, sulfur dioxide and nitric acid adsorption on calcium carbonate: A transmission and ATR-FTIR study. Physical Chemistry Chemical Physics 2005, 7, (6), 1266-1276.

8. Nakamoto, K., Infrared and Raman Spectra of Inorganic and Coordination Compounds (Part A: Theory and Applications in Inorganic Chemistry)(Volume 1A)(Part B: Applications in Coordination, Organometallic, and Bioinorganic Chemistry)(Volume 1B). NY, John Wiley \& Sons, Incorporated: 1997.

9. Börensen, C.; Kirchner, U.; Scheer, V.; Vogt, R.; Zellner, R., Mechanism and kinetics of the reactions of $\mathrm{NO}_{2}$ or $\mathrm{HNO}_{3}$ with alumina as a mineral dust model compound. The Journal of Physical Chemistry A 2000, 104, (21), 5036-5045. 
10. Sivachandiran, L.; Thevenet, F.; Rousseau, A.; Bianchi, D., $\mathrm{NO}_{2}$ adsorption mechanism on $\mathrm{TiO}_{2}$ : An in-situ transmission infrared spectroscopy study. Applied Catalysis B: Environmental 2016, 198, 411-419.

11. Zholobenko, V. L.; Plant, D.; Evans, A. J.; Holmes, S. M., Acid sites in mesoporous materials: A DRIFTS study. Microporous Mesoporous Mater. 2001, 44, 793-799.

12. Williams, D., Frequency assignments in infra-red spectrum of water. Nature 1966, 210, (5032), 194-195.

13. Wang, T.; Liu, Y.; Deng, Y.; Fu, H.; Zhang, L.; Chen, J., The influence of temperature on the heterogeneous uptake of $\mathrm{SO}_{2}$ on hematite particles. Sci. Total Environ. 2018, 644, 1493-1502.

14. Wang, T.; Liu, Y.; Deng, Y.; Fu, H.; Zhang, L.; Chen, J., Emerging investigator series: heterogeneous reactions of sulfur dioxide on mineral dust nanoparticles: from single component to mixed components. Environmental Science: Nano 2018, 5, (8), $1821-1833$.

15. Deiana, C.; Fois, E.; Coluccia, S.; Martra, G., Surface structure of $\mathrm{TiO}_{2} \mathrm{P} 25$ nanoparticles: infrared study of hydroxy groups on coordinative defect sites. The Journal of Physical Chemistry C 2010, 114, (49), 21531-21538.

16. Busca, G.; Lorenzelli, V., Infrared spectroscopic identification of species arising from reactive adsorption of carbon oxides on metal oxide surfaces. Materials Chemistry 1982, 7, (1), 89-126.

17. Walrafen, G.; Hokmabadi, M.; Yang, W. H., Raman isosbestic points from liquid water. The Journal of chemical physics 1986, 85, (12), 6964-6969. 
18. Colthup, N., Introduction to infrared and Raman spectroscopy. Elsevier: 2012.

19. Busset, C.; Mazellier, P.; Sarakha, M.; De Laat, J., Photochemical generation of carbonate radicals and their reactivity with phenol. Journal of Photochemistry and Photobiology A: Chemistry 2007, 185, (2-3), 127-132.

20. Behar, D.; Czapski, G.; Duchovny, I., Carbonate radical in flash photolysis and pulse radiolysis of aqueous carbonate solutions. The Journal of Physical Chemistry 1970, 74, (10), 2206-2210. 